The Global Health Network Collections

\title{
7 Human Milk: Bioactive Components and Their Effects on the Infant and Beyond
}

Donna Geddes, PhD, PostGrad Dip (Sci), DMU, Foteini Kakulas, PhD, BSc, Research Fellow

Published on: May 01, 2020

Updated on: May 02, 2020

DOI: $10.21428 / 3 d 48 c 34 a \cdot d e 115 c 2 a$ 


\section{Human Milk: Bioactive Components and their Effects on the Infant and Beyond}

Donna Geddes, PhD, PostGrad Dip (Sci), DMU; Foteini Kakulas, PhD, BSc, Research Fellow

\section{Expected Key Learning Outcomes}

- The main components of human milk and what they provide to the infant

- The importance of colostrum (the first milk produced after delivery)

- The importance of providing fresh mother's own milk whenever possible

- The superiority of human milk over man made formula

\subsection{What Science Tells Us about Human Milk}

Human milk (HM) contains a spectacular array of molecular and cellular components that provide nutrition, protection, and developmental signals for the infant. The human infant is immature at birth compared to newborns of other mammals; colostrum delivers a concentrated dose of immune and bioactive factors that protect the infant against pathogens and promotes immune and other system development. During established lactation, HM continues to provide components such as proteins (>900 types) that are highly bioavailable and protective for the infant; fats, especially long chain polyunsaturated fatty acids, which are implicated in cognitive function; peptides, such as the appetite control factors leptin and ghrelin that influence long-term appetite control; and sugars, such as HM oligosaccharides (HMO, >200 types) that both act as decoys for pathogens and promote the growth of beneficial bacteria. This unique fluid also contains a myriad of vitamins and minerals, some of which are influenced by the maternal diet. Further, HM contains viable cells, which range from stem cells that survive and integrate into the infant's tissues to fully differentiated milk-producing cells, and immune cells that respond to both maternal and infant infections.

The advantages that HM confers are numerous for both mother and infant, making it far superior to artificial formula that is derived mainly from cow's milk and plant sources such as soy. Breastfed infants benefit enormously compared to their formula-fed counterparts, with more optimal growth 
and development, a decreased incidence and severity of infections, and a decreased incidence of conditions including diabetes, lymphoma, leukaemia, obesity, and allergy. Importantly, mothers' health is also enhanced by lactation, with early benefits being more rapid uterine involution and weight loss along with amenorrhoea. She is also at lower risk for breast and ovarian cancer, osteoporosis and hip fractures, diabetes, and cardiovascular disease. Psychologically, she benefits from increased levels of confidence and attachment to her baby.

Many of the advantages associated with breastfeeding are delivered via the components of $\mathrm{HM}$, the concentrations of which are species-specific.

\subsection{Key Properties of Human Milk and their Functions}

HM contains macronutrients, micronutrients, bioactive molecules, cells, and microbiota, making it a dynamic living fluid that can change according to infant needs. The molecular components are either synthesised by the lactocytes or imported into milk from the breasts' blood supply [1]. The milk macronutrients fat, protein, and carbohydrate are in appropriate quantities to support optimal infant growth, but often have multiple roles, such as providing protection from infection or promoting organ and system development ( Table 7.1).

\section{Tab. 7.1 The major molecules in human milk and their functions. \\ Major macronutrients in Functions human milk}




\section{Fat}

In general

Short-chain fatty acids

Medium-chain fatty acids

Long-chain fatty acids
- Greatest source of energy (50$60 \%$ caloric intake)

- Highly variable component

- Transfer of fat soluble vitamins

- Some fatty acids have antimicrobial properties

- Source of energy

- Maturation of the gastrointestinal tract

- Source of energy

- Peripheral glucose utilisation

- Maturation of the gastrointestinal tract

- Source of energy

- Infant visual and neural development

- Antiviral and antiprotozoal effects

- Modulate the immune system 
Sphingomyelins (in milk fat globule membrane)

\section{Protein}

Casein

Peptides (derived from digestion of casein)
- Central nervous system myelination

- Improved neuro behavioural and visual development of low-birth weight infants
- Amino acids are nutritive

- Main source of calcium and phosphorus

- Softer curds, resulting in more rapid gastric transit compared to formula

- Antimicrobial, immunomodulatory, antithrombotic, antihypertensive, and opioid effects 


\section{Whey}

Lactoferrin

Lysozyme

Secretory IgA

$\alpha$-Lactalbumin
- Binds iron

- Protects against iron dependent pathogens

- Its by product lactoferricin has direct antimicrobial effects

- Bacteriostatic and bactericidal properties

- Supports growth of infant commensal bacteria

- May support infant growth particularly those preterm

- Antipathogenic effect

- Neutralises toxins and viruses

- Lactose synthesis

- Binds zinc and calcium

- Matches amino acid requirement of infant

- Immune protection

- Gut maturation and development 


\section{Bile salt-stimulated lipase \\ Mucins \\ Other proteins}

Osteopontin

Amylase

Cytokines

Haptocorrin

Growth factors

- Absorption of vitamin B12

- Antimicrobial activity

- Anti-inflammatory effect, reduces the severity of infections

- Recently been linked to infant body composition

- Stimulate cellular growth

- Involved in infant intestinal growth

- Regulation of development of multiple organs

- Anti-inflammatory properties 


\section{Carbohydrate}

\begin{tabular}{|c|c|}
\hline Lactose & $\begin{array}{l}\text { - } 30-40 \% \text { total energy } \\
\text { - Calcium absorption } \\
\text { - Prebiotic for gut colonisation }\end{array}$ \\
\hline Human milk oligosaccharides & $\begin{array}{l}\text { - Protects from infection, with } \\
\text { antimicrobial and anti-adhesive, } \\
\text { and alters host cell responses } \\
\text { - Infant brain development } \\
\text { - Prebiotic for gut colonisation }\end{array}$ \\
\hline
\end{tabular}

\subsubsection{Fat}

The fat content of HM contributes to a significant portion of the caloric intake of the term infant (50$60 \%$ ) [2]. There is enormous variation in $\mathrm{HM}$ fat content that is on average $41 \mathrm{~g} / \mathrm{L}$, with a 3 -fold variation within and between women $(22-62 \mathrm{~g} / \mathrm{L})$ [3] . This corresponds to a range of approximately 1$20 \%$ fat. Fat content changes within a feed, gradually increasing from beginning to end, and is related to the volume of milk in the breast [4]]. Interestingly, fat content appears to be at its maximum approximately 30 minutes from the end of a feed, potentially reflecting milk synthesis [5]. This creates issues when sampling for assessment or scientific research, as each mother's fat content varies differently according to milk volume. Further, factors such as gestation, stage of lactation, parity, maternal age, diet, and nutritional status are known to influence fat content. For example, a low caloric intake is associated with increased HM palmitic acid(C16) content [6], [7].

The fat globule is secreted by lactocytes. It comprises a core that consists almost entirely of triacylglycerols (TAG, 98-99\%), and a surrounding outer membrane of phospholipids, cholesterol, glycolipids, proteins, and glycoproteins. The TAGs are either saturated or unsaturated fatty acids that are either short, medium or long-chain fatty acids [8],[9]. The lactocyte is capable of synthesising only short-chain (SCFA) and medium-chain fatty acids (MCFA). Long-chain fatty acids (LCFA) and longchain polyunsaturated fatty acids (LCPUFA) are imported from the maternal bloodstream. These include the omega- 3 fatty acid docosahexaenoic acid (DHA) and the omega- 6 fatty acid arachidonic acid (AA). LCFA make up the bulk of the fat composition ( $85 \%$ ), followed by MCFA (13\%); the 
remainder are LCPUFA and SCFA. The total HM fat content is largely not affected by maternal diet [10], [11], [12] but the fatty acid composition is. For example, DHA concentration is higher in HM from women with high fish intake [1]ㅡ. whereas higher MCFA concentrations are found in HM from women consuming a low-fat high-carbohydrate diet. The infant absorbs fat from HM better than from other species' milk. This is likely due to differences in triacylglycerol structure [14] and the action of bile saltstimulated lipase, which breaks down HM fat. While HM is high in fat, there is no evidence that fat intake in the first two years of life is related to being overweight or obese later in life. However, increased protein intake is associated with rapid growth [1ㄷ] and later obesity. Further, fat intake in the first two years of life has not been associated with development of non-communicable diseases [16]. Importantly, fat also provides a means of transfer of fat-soluble vitamins to the infant.

The above,together with the brain growth-stimulating functions of certain HM fats, e.g., omega-3 fatty acids, support the beneficial rather than detrimental effects of HM fat for the infant. HM fat is important for normal infant development because DHA and AA are implicated in neural function and are integrated into the retina and brain [트] . Indeed, breastfed infants have higher levels of DHA and AA in their blood and brain (grey and white matter, and brain cortex) compared to formula-fed infants [17]. Improved visual function [17] and higher IQ is also characteristic of individuals who were breastfed as infants [17]. Stark differences have been documented between breast and formula-fed infants, with breastfed infants having higher plasma levels of DHA and AA, higher levels of DHA in the brain at autopsy, improved visual function [17]], and higher IQ (up to 15 years) compared to their formula-fed counterparts [17]. These advantages are attributed to the unique fatty acid profile of HM. Similarly, sphingomyelins (implicated in myelination of the nervous system) have been recently shown to improve neuro behavioural and visual test scores in premature infants fortified with sphingolmyelins [1ㅈ]. Some fatty acids also provide protection particularly against lipid-coated microorganisms [1ㅜ], [20] $]$, [21]]. Further, higher concentrations of HM n6 polyunsaturated fatty acids (n6 PUFAs) have been associated with lower risk of mother-to-child transmission of human immunodeficiency virus (HIV, [르]).

\subsubsection{Protein}

The nitrogen content of HM $(1.71 \mathrm{~g} / \mathrm{L} \pm 0.31)$ consists of protein (approximately $75 \%)$ and non-protein (approximately $25 \%$ ) components[를.

Non-protein nitrogen consists of molecules such as free amino acids, peptides, creatine, creatinine, nucleic acids, nucleotides, urea, uric acid, ammonia, amino sugars, polyamines, and carnitine [24]. These are functional in the infant, having effects on growth and development as well as providing protection. For example, nutritionally, nucleotides and nucleosides are involved in rapid growth (as in

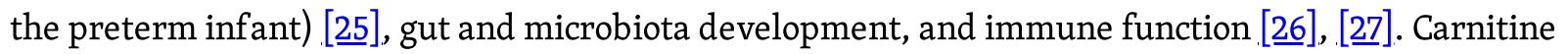


and taurine are essential for fatty acid metabolism; carnitine is involved in lipolysis, ketogenesis, and thermogenesis, while taurine plays a role in fat absorption, bile acid secretion, and hepatic and retinal function [28]. In immunity, a number of proteins and products of digestion provide protection against pathogenic bacteria and viruses, and support development of the immune system [29], [30]. Typically, many of these components have multiple functions.

Protein levels in HM are relatively low (approximately $1 \%$ on average), but they are highly bioavailable and specific to the human infant, and mainly produced by lactocytes [27]]. Protein content is highest after birth (average $15.8 \pm 4.2 \mathrm{~g} / \mathrm{L}$ ), declining to relatively constant levels in mature milk (average $6.9 \pm 1.2 \mathrm{~g} / \mathrm{L}$ ) [31]. Protein in HM accounts for $5 \%$ of the infant's energy, which satisfies the 5.6 $\mathrm{PE} \%$ (percentage protein energy, PE\%)mean protein requirement for 6-month-old infants. Infants do not therefore require extra protein, particularly considering that extra protein early in life has been associated with obesity later in life [32],[33]. As the infant grows, the required PE\% decreases to a mean of 3.8, with a safe upper level of $5.2 \mathrm{PE} \%$. PE\% in the range of 5-20 is considered acceptable for children aged 1-3 years [34]. However, this is often exceeded by 3-4 times, with the major source of protein being whole bovine milk that has $20 \mathrm{PE} \%[\underline{35}]$. Both the quality and quantity of protein consumed in the first two years of life impacts on infant growth, neuro development, and long-term health. High protein intake in these first two years has a negative impact on health [36]. Here, the protein intake of formula-fed infants is typically greater and the composition different to that of breastfed infants, particularly in relation to amino acid content. While this marked difference has compelled formula companies to produce lower protein formulae to mimic the growth rates of breastfed infants [ㅍ] , [38], the protein composition is very difficult to match. Three major groups of HM protein exist:

\section{- Caseins, as micellar structures suspended in solution}

- Whey, water-soluble proteins

\section{- Mucins, associated with the milk fat globule membrane}

\section{Casein}

Caseins are major proteins in mammalian milk and account for $13 \%$ of the total protein [27]. The high levels of caseins in bovine milk give it its characteristic white appearance, while HM has a pale blue appearance because of its low casein content. Caseins are predominantly nutritive, providing the infant with essential amino acids and minerals. The casein micelle is the main source of calcium and phosphorous, and is necessary for infant bone mineralisation [39]. The enzyme protease in the breast and the infant's stomach breaks down casein into smaller peptides that have multiple effects, 
including antimicrobial, immunomodulatory, antithrombotic, antihypertensive, and opioid effects. The low case in content of $\mathrm{HM}$ is also responsible for the slower growth rate of human infants compared to other mammalian offspring [40]. Casein is only mildly digested in the stomach [1ㅣ]. Caseins are then precipitated and more slowly digested than whey proteins. Since the casein level is lower in HM compared to cow's milk, it forms a softer curd in the stomach that is more easily digestible; it therefore passes through the stomach faster than formula, facilitating frequent breastfeeding [42] ], [43], [444]. The casein concentration of cow's milk is more than 10-times greater than of HM [ㄴ5]. Thus, the addition of whey protein to bovine-based formula [46] is necessary to offset some of the high-casein effects such as formation of hard curds in the infant's stomach.

\section{Whey}

Whey proteins account for a major proportion of protein in HM (90\% and 60\% of the total protein content in colostrum and mature milk, respectively) [41]. Whey comprises a large number of different proteins. Those abundant in the whey fraction include the major immunological proteins lactoferrin, lysozyme, and secretory IgA (sIgA) as well as $\alpha$-lactalbumin and bile salt-stimulated lipase that have nutritional roles [4]], [뇨].

Lactoferrin is present in higher concentrations in HM versus bovine milk and binds to the majority of the iron in HM [푸] ]. Infant iron uptake is assisted by lactoferrin binding to receptors on enterocytes [50], [1ㅣ. The addition of bovine lactoferrin to infant formula does not increase infant iron absorption or influence infant growth rate [드], [트] , suggesting that bovine lactoferrin either does not bind to the human lactoferrin receptor or that it is inactive due to processing [ $\underline{54}$ ]. Iron sequestering by lactoferrin deprives iron-dependent pathogens, thus protecting the infant. However, lactoferrin also has direct effects on pathogens [55] due to lactoferricin, a by-product of its digestion. Lactoferricin has strong antimicrobial effects, antiviral properties, and antitumor activity [ㄷ6], [57]. Lactoferrin also has antiinflammatory effects, particularly in the enterocytes of the gastrointestinal (GI) tract, with cell growth appearing to be dose-dependent.

Lysozyme is one of the three major proteins that dominate the whey fraction of milk. It has bacteriostatic and bactericidal properties, and its functions include breakdown of the outer cell wall of

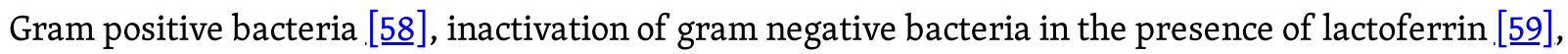
inhibition of amoebae [으], and anti-HIV activity [미]. Interestingly, HM lysozyme appears to support resident commensal bifidobacteria in the milk but inhibit growth of adult-like strains of bifidobacteria [62]. There is also evidence that lysozyme added to feeds improves growth in piglets [63], and that there is a positive association between lysozyme concentrations in HM and the growth of preterm infants [64]. With the resurgence of pasteurised human donor milk as an alternative to preterm formula when mother's own milk is not available, the reduction in concentration of lysozyme (and bile 
salt stimulated lipase) by Holder (heat) pasteurisation may impact preterm infant growth. Recently UV-C pasteurisation has been shown to reduce the loss of bioactivity and increase retention of proteins (i.e., lysozyme, lactoferrin, and sIgA), making it an attractive alternative method to retain donor milk quality $[\underline{65}]$.

o-Lactalbumin comprises $10-20 \%$ of the total HM protein [66]. It is involved in lactose synthesis [67], and also binds zinc [ㅎ8] and calcium [의]. While zinc and iron absorption improved in monkeys fed formula supplemented with bovine $\alpha$-lactalbumin [므], no studies have assessed mineral absorption in breastfed infants. Further, the amino acid composition of HM $\alpha$-lactalbumin matches the infant's amino acid requirements [71].$\alpha$-lactalbumin has been shown to protect the infant against several microbes such as Escherichia coli, Klebsiella pneumonia, Staphylococcus aureus, and S. epidermis [72]; however, its antimicrobial activity has not been intensely studied. $\alpha$-Lactalbumin has also been implicated in GI tract maturation and development [구].

Secretory immunoglobulin A (sIgA) is the most abundant immunoglobulin in HM, contributing up to $25 \%$ of total protein content [74] ]. sIgA is present in greater concentration in colostrum (7-8g/L) decreasing to lower levels $(1.0-2.0 \mathrm{~g} / \mathrm{L})$ later in lactation [75]. It provides support for the infant as their immune system matures and becomes more functional [27]. The broncho-entero-mammary pathway facilitates the infant's protective mechanisms. IgA-producing lymphocytes in the maternal bronchi and intestine are transferred to the lactating mammary gland during lactation, and then to HM [므]. sIgA protects the infant by multiple means. It prevents adherence of pathogens to the intestinal epithelial surface, and neutralises toxins and viruses [77]. Its resistance to digestion further facilitates its protective effects in the infant's gut [표].

Bile salt-stimulated lipase (BSSL; 1-2\% of total milk protein) plays an important role in the digestion of dietary fats. It is present in bovine milk but absent in infant formula due to the manufacturing process. In the intestinal lumen, BSSL is activated by bile salts allowing it to hydrolyse lipid substrates, such as short- and long-chain triacylglycerides [79]. Pasteurisation of HM inactivates BSSL and is thought to reduce fat absorption in preterm infants [80], [81]. UV-C pasteurisation of $\mathrm{HM}$ has been shown to preserve most of the BSSL activity [2] , potentially improving fat absorption in the preterm infant, although this has not been tested clinically.

\section{Mucin}

Milk fat globule membrane proteins include lactadherin, butyrophylin, xanthine oxidase, and mucins. Few mucins have been studied. Mucin 1 appears to inhibit pathogen binding to the host cell surface, and specifically binds to rota viruses. 


\section{Other proteins}

Osteopontin levels are higher in HM than in bovine milk (ratio approximately 10:1) [73] . It has important functions in the development of the gut barrier, and modulates growth factor TGF- $\beta 1$ and pro-inflammatory cytokines in mice with induced colitis, thus reducing inflammation [ $\underline{83}]$. There is evidence that both human and bovine osteopontin affect gene expression in the Caco-2 human intestinal cell line, albeit differently. Addition of human or bovine osteopontin to formula-fed infant rhesus monkeys demonstrated that the two osteopontins had different effects in pathways related to development, immune response, galactose metabolism, and cytoskeleton remodelling [84]. A more recent study in human infants showed that osteopontin supplemented formula did not affect growth, but reduced the incidence of infection versus normal formula, suggesting that osteopontin influences immune function [85].

o-Amylase is present in higher concentrations in HM than in duodenal fluid; its activity is highest in colostrum (when salivary and pancreatic $\alpha$ amylase activities are low), and decreases with established lactation (days 15-90) [6]. $\alpha$-Amylase is active at low $\mathrm{pH}$, equivalent to that in the infant's stomach (5.3), and is therefore resistant to degradation [86]. It plays a role in digestion of oligo- and polysaccharides [72] , and may also exert antibacterial functions by breaking down polysaccharides in bacterial cell walls [87].

Haptocorrin binds most of the vitamin B12 in HM [요]. Evidence suggests haptocorrin resists digestion, and is taken up by human intestinal cells through binding of holo-haptocorrin to the intestinal brush border [89]. As such, the infant absorbs vitamin B12 early in life. In addition, haptocorrin has exhibited antimicrobial activity [르].

Cytokines in HM, of which 80 have been measured, possess immunomodulatory functions; they include interleukin (IL)1 $\beta$, IL6, IL8, IL10, tumour necrosis factor- $\alpha$ (TNF- $\alpha$ ), transforming growth factor- $\beta$ (TGF- $\beta$ ), and interferon gamma (IFN- $\gamma$ ) [90]. Many cytokines are anti-inflammatory and likely decrease infection severity in breastfed infants. Interestingly, certain cytokines (IL-6 and TNF$\alpha)$ have been linked to infant body composition, with higher IL- 6 concentrations associated with less body weight gain, percentage body fat, and fat mass; and TNF- $\alpha$ associated with less lean mass [91].

Growth factors present in HM include epithelial growth factor (EGF) and insulin-like growth factor (IGF)-1, IGF-II, insulin, and relaxin. Growth factors stimulate cellular growth, and those aforementioned have been implicated in the stimulation and regulation of infant intestinal growth [92]. EGF has multiple functions, including regulation of mammary, hepatic, pancreatic, and lung development [91]. TGF- $\beta$ is higher in colostrum than mature milk. However, lower levels have been found in the milk of preterm mothers whose infants had necrotising enterocolitis; as this was shown in a study of small sample size, this finding remains to be confirmed [푸] . Nevertheless, it is feasible that 
TGF- $\beta$ has such a clinical effect because the severity of necrotising enterocolitis can be reduced by enteral administration of TGF- $\beta$ [며]. This effect has been attributed to the anti-inflammatory effects of this molecule.

Given the important roles that cytokines and growth factors in HM play in the protection and development of the infant, particularly the preterm infant, it is relevant to understand whether these factors are preserved in donor milk. Donor milk is used with increasing frequency as an alternative to infant formula for the preterm infant, when mother's own milk is not available or insufficient in volume. Donor milk is most often pasteurised to remove pathogenic bacterial and viruses, and Holder pasteurisation is the most common method used $\left(62.5^{\circ} \mathrm{C}\right.$ for 30 minutes). Levels of an array of factors, including EGF, IL-4, IL-6, IL-8, IL-10, TNF- $\alpha$, macrophage inflammatory protein- $\alpha$ (MIP-1 $\alpha$ ), monocyte chemotactic protein (MCP), and interferon gamma inducible protein-10 (IP10), appear to be unaffected by the pasteurisation process, but whether they remain functional remains to be determined [95]. Notably, infant formula does not contain any of these factors.

\subsection{Carbohydrate: Lactose}

Lactose is the main carbohydrate in HM, comprising 30-40\% of the total energy [96] , and has a role in calcium absorption. Lactose concentrations increase from $19 \mathrm{~g} / \mathrm{L}$ in colostrum to $54 \mathrm{~g} / \mathrm{L}$ at the initiation of lactation [97]. Lactose is broken down by the enzyme lactase into monosaccharides, glucose, and galactose. Galactose is then converted to glucose in the liver. Both galactose and glucose provide fuel for the brain, with galactose being implicated in rapid brain development. Lactose along with HMOs assist colonisation of the infant gut [요].

\subsubsection{Human milk oligosaccharides (HMOs)}

Human milk oligosaccharides (HMOs)are the third most prevalent milk component; highest concentrations are found in colostrum (20-25g/L) compared with mature milk (5-20g/L). More than 200 HMOs exist in HM, with types varying from 23 to 130 among women [99]. HMO composition is further classified into secretors and non-secretors, and these are either Lewis positive or Lewis negative. HMOs are not readily digested in the stomach, with only a small amount absorbed; thus, they do not contribute greatly to infant nutrition, but rather have a wide variety of protective functions [100], [101]. However, there is evidence to suggest that the HMO composition of milk may have a role in infant growth and body composition in the first six months of life [102]. Further, sialylated HMOs are major nutrients for infant brain development, and sialic acid concentrations are higher in breastfed infants' brains than in formula fed infants [103]. 
HMOs have an anti-adhesive antimicrobial action, which provides protection from pathogenic diarrhoea-causing organisms, such as E. coli, Campylobacter jejuni, Norovirus, and Rotavirus. The protective effects are dose-dependent, with more HMOs conferring a lower the risk of diarrhoeal disease [101]

. HMOs are also associated with reduced HIV transmission [104], a reduced risk of respiratory and urinary tract infections [100], and some protection from specific protozoa such as Entamoeba histolytica [105] through alteration in intestinal cell gene expression. Group B Streptococcus proliferation [106] and invasion of premature intestinal cells by Candida albicans is reduced by HMOs [107]. Additionally, HMOs have prebiotic effects, providing metabolic substrates for the growth of bacteria such as bifidobacteria and lactobacilli [101], [108]. Indeed, HMOs are the first prebiotic encountered by the infant at or shortly after birth. Due to the variability of HMO composition between women, the prebiotic effects on gut microbiota and health are likely to differ between infants [1ㅣ] $]$.

\subsection{Vitamins and Minerals}

Human milk provides a full complement of both water- and fat-soluble vitamins and minerals for the infant [109]. The vitamin content of HM is influenced by maternal vitamin status, particularly for those that are water-soluble. It is important that thiamine (B1), riboflavin (B2), vitamins B6 and B12, vitamin $\mathrm{A}$, iron, and iodine are consumed in sufficient amounts by the mother to ensure that satisfactory levels are delivered via milk to the infant [110]]. In contrast, levels of total calcium $(250 \mathrm{mg} / \mathrm{L})$, phosphate $(150 \mathrm{mg} / \mathrm{L})$ in HM are independent of maternal diet.

Vitamin D is produced by skin when exposed to ultraviolet light. It is critical to bone health as it is involved in the regulation of calcium and phosphorus absorption by the infant. It is also important in innate and adaptive immune system health. HM concentrations of vitamin D (25-hydroxyvitamin D) are linked to maternal serum concentrations, with low vitamin D levels in milk associated with low levels in maternal serum concentrations [111], [112], [113]. Because of the increased risk of skin cancer, there is concern that the precautions taken against excess exposure to sunlight has resulted in an increase in cases of maternal vitamin D deficiency. This is reflected in the increased incidence of rickets [114]. Where maternal vitamin D deficiency is suspected, vitamin D supplementation has been shown to directly increase both HM vitamin D concentration and infant 25-hydroxyvitamin D status [115]. Regardless, the American Academy of Pediatrics currently recommends that breastfed infants be supplemented with $400 I U /$ day of oral vitamin D from birth [116].

Iron The infant readily absorbs iron in HM and therefore supplementation is not generally required in the first six months. Exceptions include infants born with low iron stores, such as low birth weight infants and infants of mothers with diabetes [117]. Recently, a study demonstrated that $36 \%$ of healthy 
fully breastfed 5-month-old infants had iron deficiency [118]. Supplementation of breastfed infants (16 months of age) with $7.5 \mathrm{mg} /$ day of the elemental iron ferrous sulphate has been found to increase both haemoglobin concentration and mean corpuscular volume compared with non-supplemented breastfed infants [119]. Supplementation also appears to improve infant visual acuity and mental and psychomotor neurodevelopment. These studies have led the American Academy of Paediatrics to recommend $1 \mathrm{mg} / \mathrm{kg} /$ day oral iron supplementation of exclusively breastfed term infants and infants receiving more than half of their daily feeds as breast milk from 4 months of age [120].

HM contains an extensive array of trace elements (i.e., copper, zinc, barium, cadmium, caesium, cobalt, cerium, lanthanum, manganese, molybdenum, nickel, lead, rubidium, tin, and strontium) that are easily absorbed by the infant. HM concentrations of these trace elements are influenced by maternal diet, although no global reference values for levels in HM milk exist.

Zinc deficiency is not uncommon (>20\%) [121], [122] with half of all zinc deficient infants being less than 5 years of age. Zinc deficiency is indicated by symptoms including growth retardation, reduced immune function, and GI effects such as diarrhoea. Rapid growth and tissue synthesis requires high levels of zinc. Thus, infants at particularly at risk of zinc deficiency are those who are premature, of low-birth weight, or on a combination diet of HM and plant-based foods of low zinc content [123]. HM zinc levels are not influenced by maternal diet, and supplementation is generally recommended only if complementary foods are low in zinc or in poor resource settings [123].

\subsection{Human Milk Microbiome}

Emerging evidence suggests that colonisation by microbes of the infant gut early in life programmes beneficial long-term health outcomes. It is also believed that in the first two years of life the gut microbiome is relatively plastic allowing for intervention,whereas in adult life it is much more difficult to change. Conventional belief was that the infant was sterile at birth and bacterial colonisation began after birth. However, more recent evidence has shown that the gut is first colonised in utero via the placenta and amniotic fluid, and the composition is modified by mode of delivery [124]. In the immediate postpartum period and up to two years of life or beyond, HM provides a continuous source of commensal, mutualistic, and potentially probiotic bacteria for the infant gut. Indeed, significant differences in gene regulation of intestinal cells have been demonstrated between breastfed and formula-fed infants. Up-regulated genes include those involved in the control of cell differentiation and proliferation as well as barrier function in the breastfed infant. Down-regulated genes in the breastfed infant include those that control hypoxia and apoptosis [125].

HM normally contains an abundance of bacterial species, with hundreds of thousands to tens of millions of bacteria being consumed by the infant daily [3] $]$. The origin of these bacteria is still not 
clear, although the maternal gut is favoured [124]. Bacteria are transferred via dendritic cells into the lymph or blood and are then transferred to milk. Other sources of colonisation may include the maternal skin and the infant's oral cavity.

Interestingly, breastfed infants exhibit a lower microbial diversity in their intestinal tract compared with their formula-fed counterparts, but they harbour twice as many Bifidobacterium spp. cells. Bifidobacteria are predominant in faecal samples of both breastfed and formula-fed infants, but concentrations in formula-fed infants are approximately half that of breastfed infants [126]. This is speculated to be due to HM bioactive components that favour these bacterial species. However, HM microbial patterns appear to be highly individualised, and remain relatively stable, in terms of the proportion of bacterial genera over the first nine months of lactation.

The factors responsible for individual variation between women are unknown [127], but may be related to diversity of the maternal diet that influences gut flora in the short-term [128]. Further to maternal diet, factors shown to influence HM bacterial diversity between women include whether it is colostrum or mature milk, maternal obesity [129], and mode of delivery (vaginal birth versus elective caesarean section). Delivery mode differences indicate that labour and passage through the birth canal influences HM colonisation [129]. Antibiotics taken by the mother appear to have a disruptive effect on the infant microbiome [130], which is somewhat mitigated by breastfeeding [130], [131], [132]. Antibiotics also affect the HM microbiome, decreasing lactobacilli and bifidobacteria, which has been linked to infant colic [133].

HM contains HMOs that are not found in cow's milk and act as prebiotics. The HMOs reduce the $\mathrm{pH}$ of the infant's gut and increase the proportions of beneficial bacteria Bifidobacteria longus and B. longum, while decreasing E. coli and Clostridium perfringens [134]. Moreover, sIgA, which is abundant in HM, has been shown to play a role in the maintenance of a healthy gut microbiome in animal models [135]. These observations further emphasise the uniqueness of HM, with many of its components working synergistically to ensure optimal health and development of the infant. The specific roles of HM bacteria have not yet been elucidated; however, some strains have been shown to inhibit HIV in vitro[풍]

\subsection{Appetite Factors}

Breastfeeding is associated with lower rates of obesity later in life (12-24\% risk reduction) [137]. Causation cannot be inferred due to the inability to control for confounders, such as maternal body mass index, socio-economic status, ethnicity, and between-study differences in methodology and data analysis. Several factors have been implicated in the programming of appetite early in postnatal life, such as milk composition, breastfeeding behaviour, and feeding mode (breast or bottle) [르] ]. Indeed, it 
is well documented that when infants are breastfed on demand they self-regulate their milk intake [3] , [32] as they rarely drain the breast of milk. Indeed, if milk production is increased by breast expression they do not consume more milk [표] $]$.

In addition, patterns of milk intake are highly individualised, with different feeding patterns existing between infants consuming similar amounts of milk over a 24-hour period [ㅍ]. Conversely, bottlefeeding tends to encourage infants to empty the bottle and, in the longer-term, to behaviours (e.g., finishing all food on the plate) that may result in a reduced or diminished ability to self-regulate food intake [139]. This is in accordance with the higher weight gain in bottle-fed infants irrespective of whether they are fed formula or HM [140]. Furthermore, it suggests that the mode of feeding, which can influence volume intake, has a significant impact on appetite regulation and satiety cues.

Although its composition is highly variable both within and between mothers, $\mathrm{HM}$ also contains hormones controlling appetite, such as insulin, leptin, ghrelin, and adiponectin [141]. These components are highly likely to be bioactive and bio available to the infant via a number of pathways, including the high $\mathrm{pH}$ and permeability of the infant's gut [142], [143] that enable molecules to be absorbed readily. Further, there are known adipokine receptors in the GI tract to which the molecules may bind [144]. Proteolysis of these components is less likely due to the infant's immature pancreatic function and the high protease inhibitor content of HM [15] $]$. Paracellular diffusion that is enhanced in infancy is a further mechanism of absorption[1ㄷ] $]$.

Hormones controlling appetite are synthesised primarily in adipocytes [147], but also in other cell types [148], [149]. In HM, appetite hormones such as insulin, leptin, ghrelin, and adiponectin, are thought to originate from the maternal bloodstream and from their endogenous production in the mammary epithelium [150], [151], [152]. Nevertheless, the relative contributions of these molecules to HM by the maternal circulation and mammary gland are unknown, and may indeed vary both within and between women. Maternal adiposity, which is influenced by the mother's diet, can influence the maternal serum and HM concentrations of some appetite hormones such as leptin [ㅌ53]. However, no association has been found for other hormones controlling appetite such as adiponectin [1 $\underline{154}]$.

\subsection{Metabolites}

The current approach to biological research involves the study of whole system biology. Since the postgenomic era, research has focused on alterations in mammary gene expression at the RNA level (transcriptomics) and at the small molecule metabolite level (metabolomics), with the aim of gaining new insights and better understanding of the biological function of cells and organisms [155]. Metabolites that are less than 1.5k Dain size are end products of cell function and metabolism [156]. Therefore, among the "omic" technologies, metabolomics (the study of metabolites) is suggested to 
provide the most "functional" information, reflecting the physiological, evolutionary and pathological state of a biological system. Changes in the transcriptome and proteome do not always result in biochemical phenotypes (the metabolome) [157].

Advancement in technology and techniques, including nuclear magnetic resonance (NMR), capillary electrophoresis (CE), gas chromatography (GC), and liquid chromatography (LC), have helped unravel

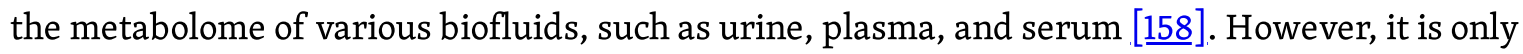
recently that attempts have been made to profile the HM metabolome. Marincola, et al. used proton NMR (1H NMR) and GC-mass spectrometry (MS) to compare preterm HM with preterm formula. Statistical analysis showed distinct differences between HM and formula,with higher levels of oleic and linoleic acids measured in formula [토]. Different metabolic HM profiles between mothers of preterm infants with various gestational ages (23-25 weeks and $\geq 29$ weeks) [ $\underline{160}]$ and differences in HMOs in terms of secretors and non-secretors [161] have also been observed. Additionally, milk nucleotides, which play a significant role in encoding genetic information and signal transduction, have been detected using CE-MS in untreated and in pasteurised milk (either by heat or high pressure treatment) [162]. HMO profiles have been characterised using this technique in both HM and in faeces of breastfed infants [163].

An extensive study of the HM metabolome was carried out following the development of a simple and quick extraction method for HM. This method used a small amount of HM $(50 \mu \mathrm{L})$ only and enabled analysis with various instrument platforms (GC-MS and LC-MS) [164]. Based on this approach, hundreds of compounds from various compound classes (e.g., glycerolipids, sphingolipids, and carbohydrates) have been identified demonstrating the complementary nature of the HM profiling techniques. Another study employing various extraction solvents (chloroform/methanol and MTBE) and techniques for analysis (GC-MS, LC-MS, CE-MS, and 1H NMR) demonstrated the metabolite complexity of HM, identifying more than 700 compounds in term milk [165]. However, given the complexity of the HM metabolome, metabolomic profiling of HM and the effects of HM metabolites on the infant are still in their early stages.

Various factors such as time of collection(particularly in relation to feeding), stage of lactation, and maternal diet can influence the metabolomic composition of HM. These factors not only make analysis challenging, but are also difficult to control or standardise. Other interactions between the mother and the dyad, such as gut microbiome and glycan digestion by microbes, can also greatly influence dyad health and require further investigation [166], [167]. Metabolomics analysis combined with other 'omics' technologies will provide valuable insight into the functional capacity of human lactation as an entire biological system. 


\subsection{New Discoveries}

\subsubsection{Cells}

For over a century, scientists have known that milk is a cellular fluid, containing various maternal cells that appeared to be primarily of epithelial and immune origin [168], [169], [1ㅁ] ] Fig. 7.1. More recent studies harnessing modern analytical technologies, such as singe-cell and gene expression analyses, have revealed a diverse cellular composition in HM. These range from an epithelial cell hierarchy reflecting the lactating breast (i.e., stem cells, progenitor cells, more differentiated milk-secretory cells, and myoepithelial cells) to immune cells originating from maternal blood that protect the breast and infant [171], [172], [173], [174], [175].

\section{-Fig. 7.1}

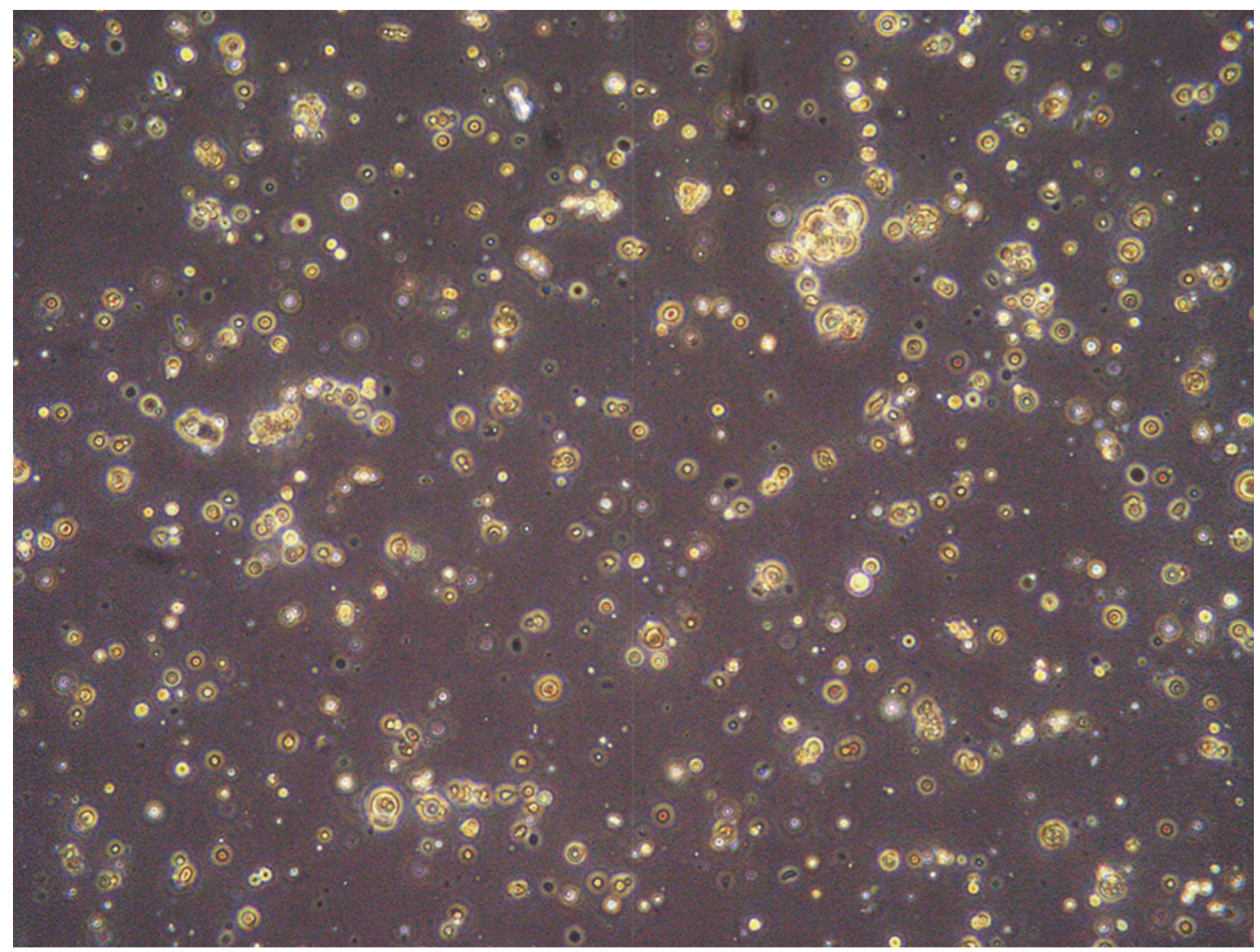

Freshly isolated human milk cells stained with Trypan Blue for cell viability. Cells stained dark blue indicate dead or dying cells. 
Numerous maternal and infant factors are known to influence the cellular content of HM, including (a) breast fullness; (b) stage of lactation; (c) health of the mother and infant; and (d) developmental status of breast epithelium [176], [177], [175], [174], [177]. In addition to environmental influences and normal biological variation both within and between women and other mammals, methodological differences between studies and use of non-specific marker technologies have introduced variation in the reported proportions of the different cell types in HM [180]. While mature HM (after the first two weeks postpartum) is dominated by epithelial cells, colostrum contains high proportions of immune cells in accordance with the needs of the immunologically immature newborn [172]. Numbers of immune cells also greatly increase during lactation in response to mother and/or infant infections, providing specific protection of both breast and infant when needed [175]. Further, HM and other species' milks have been shown to be rich sources of stem cells, which are viable, survive in the infant's GI tract and integrate into different tissues, potentially exerting different functions [173].

\section{Stem cells in breast milk}

Until recently, stem cells were thought to be present only deep within tissues, away from external chemical influences, to preserve their identity and function. Indeed, except for in the embryo, stem cells are found in postnatal organs, with the specific role of tissue repair and regeneration during life. However, stem cells have also been found in body fluids, including the blood, saliva, urine, and milk [179], [30], [180], [181]. Particularly in HM, a cellular hierarchy has been described. This includes earlystage stem cells that are capable of self-renewal and differentiation into cells from all three germ layers, and their breast-derived progeny. The latter are more differentiated epithelial cells, such as lactocytes (milk-secretory cells) and myoepithelial cells [181], [172], [173]. These HM stem cells and their progeny provide a novel non invasively-accessed source of lactating breast epithelial cells, opening new avenues for investigation of the biology of the human lactating breast and associated pathologies such as low milk supply.

Milk stem cells have been shown to display non tumorigenic multilineage differentiation properties in vitro. This means that they have the capability of turning into various cell types in culture, such as breast cells that produce milk components, and brain, liver, pancreatic, bone, joint, and heart cells [181]. They also survive in the GI tract of the offspring in vivo [182]. Recent studies in a mouse model demonstrated numerous milk-derived stem cells present intact in the stomach as well as in the thymus, liver, pancreas, kidneys, spleen, and brain of nursing pups. There, they appeared to selfrenew, differentiate into tissue-specific cells, and integrate into different organs, potentially contributing to function [182]. They were also detected in the pups' blood at levels up to $1.2 \%$ of total cells both during and after the nursing period, and into adulthood. This phenomenon of transfer and integration of allogeneic cells into host tissues (in this case from mother to offspring) is called microchi- 
maerism and is known also to occur from mother to foetus and vice versa during pregnancy [183], [184]. The functional significance of microchi-maerism between mother and offspring in utero and via breastfeeding has not been established. However, developmental roles are proposed for cells that are actively transferred to the host, remain alive, integrate in host tissue, and maintained in host tissue to adulthood. Similarly, milk derived immune cells have been shown to survive in the GI tract of nursed offspring and migrate to different organs, where they provide immunological support early in life [185], [186].

\section{Protective cells in breast milk}

The immunological protection the mother provides to the foetus in utero, together with beneficial microbiota, developmental signals, and nutrients, continues postnatally during breastfeeding. Numerous studies have demonstrated the lower risk of disease and infection in both the short and long term conferred by breastfeeding, with significant reductions in infant and child mortality [187], [188], [189]. These effects are related to HM immunomodulatory biomolecules, such as sIgA, lactoferrin, $\alpha$-lactalbumin, oligosaccharides, and cytokines. They are also related to immunocompetent cells that originate from the maternal circulation and comprise an important HM component that acts synergistically with immunomodulatory biomolecules. HM delivers thousands to billions of viable immune cells to the infant daily [175], [174]. Recent studies using modern state-of-theart techniques such as flow cytometry, which enables accurate marker-specific (not morphological only) single cell analysis, have shown that immune cells are not dominant in mature HM as previously thought. Compared with mature HM, HM immune cell content is significantly higher in the first few days postpartum [175]. This concurs with a time when the infant is particularly susceptible to infections, since its own immune system is still immature [190], with immune cells often comprising the majority of HM cells. However, by week 2 after birth, the HM immune cell content drops to approximately $1-2.5 \%$ of total cells. This low proportion is maintained throughout lactation except for periods of infection of the mother, the infant, or both [175]. Yet, this small proportion of immune cells corresponds to the high numbers of immune cells ingested daily by the infant in HM (range approximately 94,000-351,000,000 [175]). These immune cells include those typically found in blood (monocytes, macrophages, granulocytes, $\mathrm{T}$ - and $\mathrm{B}$ lymphocytes), with monocytes usually dominating the immune cell component of HM. However, infection can alter both the total number of immune cells in HM and the proportions of the different sub types. During a breast, another organ, or systemic infection, immune cells rapidly increase in HM, reflecting the specific infection and its severity [175], [174] (_Fig. 7.2). Upon recovery, HM immune cells then return to normal baseline levels characteristic of the mother-infant dyad. This rapid immune cell response of $\mathrm{HM}$ has been shown to be more consistent and dynamic than the response of humoral HM factors. Thus, it could be used to monitor treatment response of a lactating mother, which could prove to be particularly useful in the treatment 
and management of mastitis [175]. Remarkably, HM responds not only to infections of the mother, but also of the infant, even when the mother is asymptomatic [174], [1777], [191].

Fig. 7.2

Colostrum

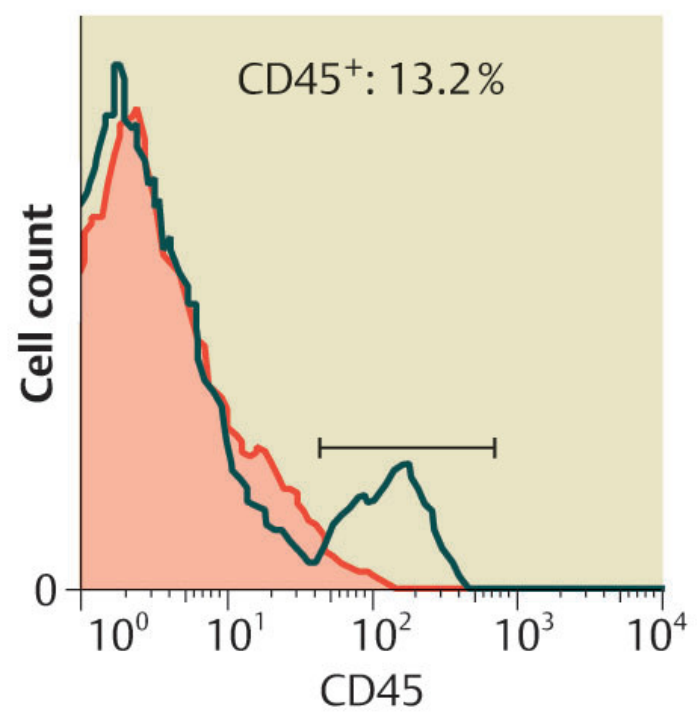

Week 10 postpartum

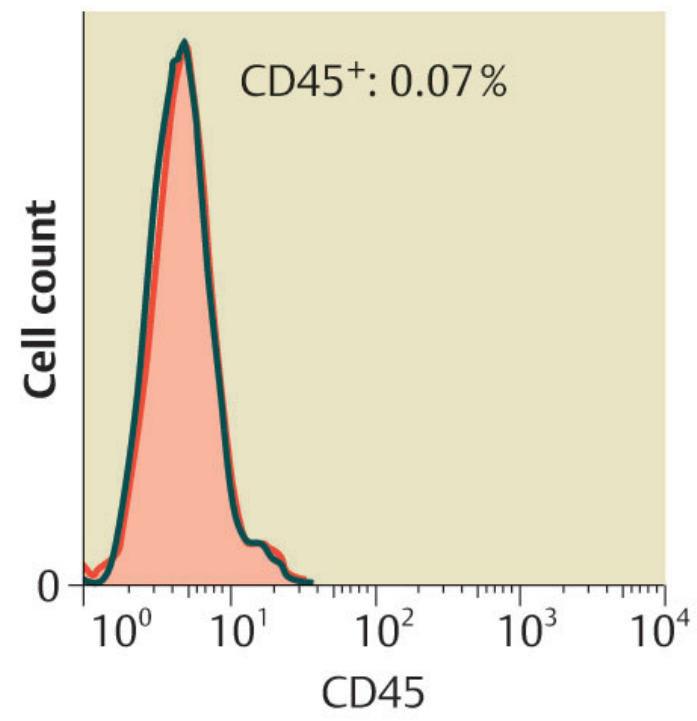

Week 2 postpartum

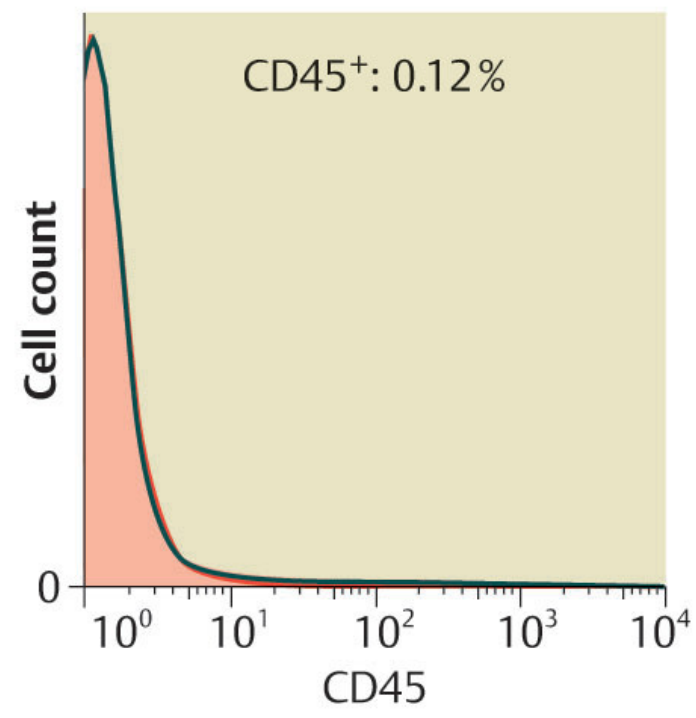

Immune cell content (\%)

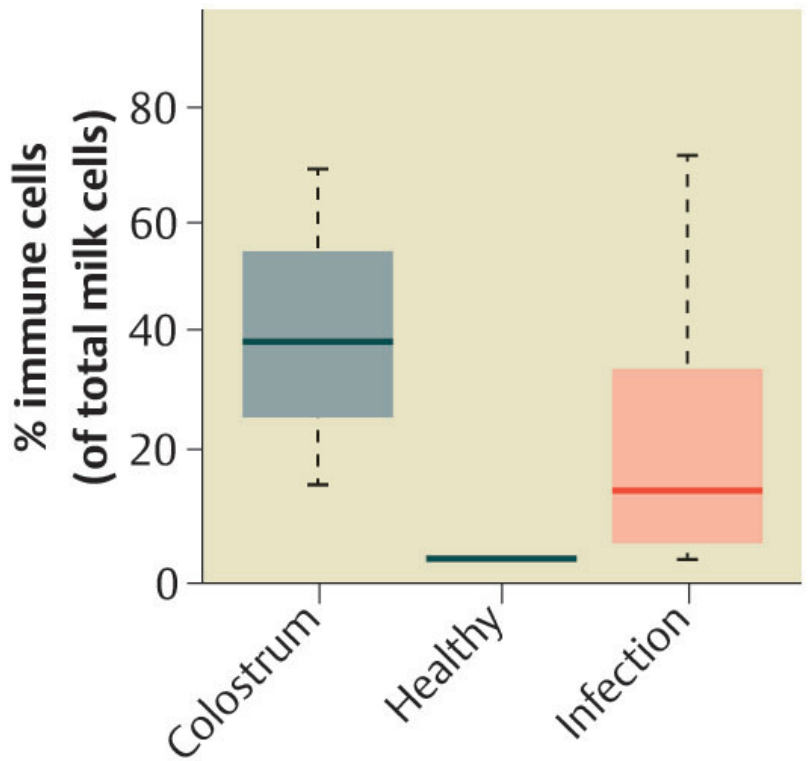

Changes in HM immune cell (CD45+) content from colostrum to week 10 postpartum, and between HM samples collected from healthy and infected mother-infant dyads. Maternal and infant infections stimulate a rapid leukocyte response in breast milk. (Modified from Hassiotou, et al. Clin Translat Immunol 2013; 2: e3.) 


\section{DFig. 7.3}

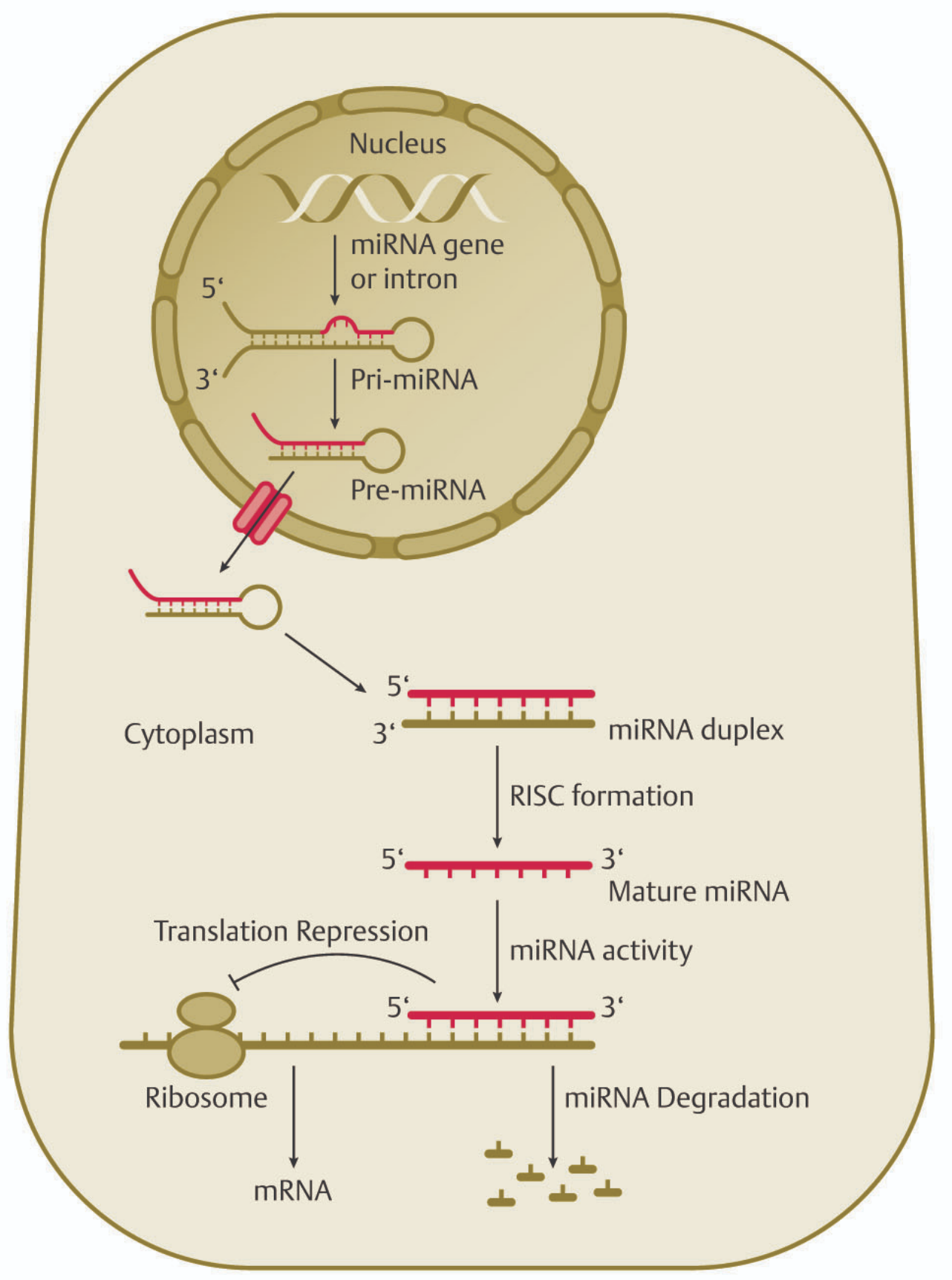

The current model of miRNA biogenesis and the proposed model of gene expression regulation. RNA polymerase II/III processes primary miRNA (pri-miRNA) from either independent specific genes (miRNA genes) or from introns (protein-coding genes). Inside the nucleus, precursor miRNA (pre-miRNA) is processed from pri-miRNA by the DroshaDGCR8 complex. Then, premiRNA is transported to the cytoplasm by Exportin 5, where Dicer processes the miRNA duplex. Only one strand of the miRNA duplex (called mature miRNA) is attached to the RNA-induced silencing complex (RISC), which can bind its target (mRNA) for either translation repression or mRNA. 
The backwards flow of milk during milk ejection has been proposed to facilitate this immune cell response, providing specific immunity to the infant's infection and immunological protection related to the infant's needs [174]. Indeed, HM immune cells similar to stem cells survive in the GI tract of the offspring and migrate into different tissues, supporting their role in boosting infant immunity early in life [175], [185], [186].

\subsubsection{MicroRNA}

Infant immunity is not only boosted by immunocompetent immune cells and molecules such as immunoglobulins, lactoferrin, and lysozyme in HM, but also by small RNA molecules called microRNAs (miRNAs). These are non-coding long RNAs containing about 22 nucleotides. They are abundant in tissues, organs, and body fluids, such as plasma, urine, saliva, seminal fluid, tears, cerebrospinal fluid, and in milk [192] (_Fig. 7.3). They are known to play key roles in regulating gene expression at the post-transcriptional level, and are involved in all major biological processes, including cell differentiation, cell cycle, apoptosis, immunity, and development, and in disease [193], [194]. Since their discovery in HM and other species' milks, very little has been done to address their origin, levels, properties, function in the lactating breast, and fate in the breastfed infant. What recent studies have clearly shown is that the miRNA composition of HM is mother-infant dyad specific [195], similar to that previously reported for other HM components, such as HMOs.

To date, 2,588 mature miRNAs are known to be present in humans (miRBase version 21.0, release 2014) [196], of which more than half have been found in HM [195]. In addition to these known miRNA species, thousands of novel miRNA species have been recently identified in different fractions of HM. The cell fraction of HM has been shown to be one of the richest sources of miRNA, followed by miRNA embedded within the milk fat globule [195], [197]. In milk, in particular HM, miRNAs are present in all major fractions, including cells, lipids, and skim milk, and protected within microvesicles such as exosomes [195]. Their specific 'packaging', along with the infant's more alkaline stomach pH [198] and higher gut permeability compared to the adult [143], contributes to HM miRNA survival in the breastfed infant, their absorption into the bloodstream, and transfer to various organs where they may exert immunomodulatory and developmental functions[195].

Indeed, recent small RNA sequencing studies in different HM fractions have revealed that known and novel miRNA molecules are abundant in HM and are key regulators of immune responses, body fluid balance, thirst, appetite, and system development, including the neural and immune systems.

As such, a functional significance for miRNAs is suggested in the infant [195]. Further, study of the uptake of exogenous food-and bovine milk-derived miRNAs in the adult GI tract has indicated high 
stability (in contrast to messenger RNAs), even in the adult gut, uptake into the blood, and function in specific organs such as the liver [199], [200], [201], [202], [203], [204].

Recently optimised methodology to extract miRNAs from different HM fractions has emphasised the importance of standardisation and optimisation of milk collection, storage, and processing for comparative miRNA studies [195], [199]. Particularly for studies investigating the miRNA content of different milk fractions, milk fractionation prior to freezing (instead of storing whole milk) ensures that the miRNA content integrity of each milk fraction is maintained and cross-contamination between fractions during freezing is avoided [195]. Moreover, each milk fraction requires a slightly different procedure for optimal miRNA extraction. The filter column-based extraction method provides better miRNA yields and quality compared to other published methods such as those based on phenol/chloroform [197]. These optimisation studies provide a basis for more comprehensive miRNA profiling analyses of HM and other species' milks.

Although factors that may influence HM miRNA content and composition are not well established, studies have recently shown that milk removal during breastfeeding and lactation stage can affect the HM composition with regard to miRNAs. Postfeed milk is known to contain more cells than pre-feed milk [5] , and post feed milk cells were shown to contain more miRNAs, some of which were up regulated post-feeding [205]. Many of the up regulated miRNAs were associated with the synthesis of milk components, reflecting changes occurring in the mammary gland in response to milk removal by the infant. In addition to these short term changes, long-term changes in HM miRNA composition with lactation have also been demonstrated. In a study examining the HM miRNA profile in the first six months of lactation, approximately one third of miRNAs were differentially regulated. This was despite similar expression of $70 \%$ of commonly identified miRNAs in milk cells and lipids. Most changes occurred around month 4 of lactation, during the transition from exclusive to non-exclusive breastfeeding [206]. Further studies are required to determine the dynamic short- and long-term changes in HM miRNA content, and how these can be used to improve understanding and assessment of lactating breast function and the diverse roles of HM in the infant.

\subsection{What Does the Future Hold?}

Among the different HM components with bioactivity in the infant, cells, miRNAs, and metabolites can be used as novel diagnostic markers of lactating breast health status and performance. For example, in a recent gene expression study in stem and other cells of the lactating breast accessed via HM, differences in breast epithelium maturation between mothers who gave birth at term and preterm, and between obese and non-obese mothers were identified [207]. These findings provide a potential molecular explanation for the low milk supply that is often seen in mothers giving birth preterm and 
who are obese. Thus, gene expression analyses of HM cell content could potentially be used as an indirect indicator of breast maturation and in the management of low milk supply [207], [178].

Moreover, recent miRNA studies in the mammary gland and HM have identified miRNA candidates as potential biomarkers of lactation performance. In addition to their involvement in mammary gland development [208], [209], the types and expression levels of miRNAs differ distinctly between lactating and non-lactating mammary glands [210]. More specifically, miR-29s were found to regulate important lactation-related genes in mammary epithelial cells in the dairy cow, while decreased miR29s expression was associated with reductions in lactoprotein, triglycerides, and lactose [211]. Further, miRNAs of the lactating gland accessed via HM have been shown to originate primarily from the lactating epithelium [195], and to be involved in the synthesis and regulation of milk nutritional components (e.g., lactose, triacylglycerol, fatty acids, growth hormone, and insulin receptor) in immune responses and in development [195]. These findings make HM miRNAs attractive targets for diagnostic studies of lactating breast function.

Milk miRNAs have been shown to respond to infections of the lactating udder in the cow [212], [213], implicating their involvement in dynamic immune responses to gland infections. In addition to milk miRNAs, the rapid HM immune cell response to breast infection could provide a novel means to assess mothers' response to treatment. More specifically, mastitis is a serious infection of the lactating breast that causes pain, inflammation, and irritation, symptoms that often persist and result in premature cessation of breastfeeding. HM immune cell profiles specifically change during mastitis; they continue to change while the inflammation is resolving [174], providing an easily assessable marker to monitor infection, facilitating early and effective intervention, and enabling continuation of breastfeeding.

A better understanding of factors that influence HM composition can open new avenues for specialised patient-specific treatment of fragile infants, such as those born preterm,or with specific genetic conditions or deficiencies. For example, it is still not well understood how the maternal diet affects HM composition, with effects on fatty acids being reported. Moreover, physicians can take advantage of the dynamic composition of HM to boost growth and development of preterm infants. It is long known, for example, that post-feed (hind) milk is significantly richer in fat than pre-feed (fore) milk. Selective feeding of the preterm infant with post-feed milk may confer developmental benefits, and requires further investigation. In addition, new understanding of the importance of the HM microbiome in infant gut and immune system development, and its specificity for a given motherinfant dyad, has triggered investigations of refaunating donor HM with mothers' own milk [214].

Over the years, it has become clear that different HM fractions(cells, lipids, and skim milk) have different properties and contain different components, each contributing unique and important functions in the infant. It is therefore important to maintain the functional integrity of these components when expressed milk is provided to the infant. This is better achieved when HM is given 
fresh (not previously frozen or processed) to the infant. In susceptible infants such as those born preterm, frozen and pasteurised milk has been typically administered in neonatal intensive care units (NICUs) due to organisational constraints and safety concerns. Yet, in more recent years, some NICUs around the world are exclusively providing fresh, unfrozen, unpasteurised mother's own milk to preterm infants, with positive outcomes. This practice ensures provision of live cells, stem cells, and protective immune cells to the infant, which otherwise would be excluded from their diet. Additionally, miRNAs with potential important regulatory, immunoprotective, and developmental functions are present in HM cells and other components.

Further investigation of the benefits and safety of providing fresh, unfrozen, and unpasteurised HM to preterm infants is needed to address the effects of withdrawing such HM components from the preterm infant diet. This is particularly important as they could potentially improve infant development, provide additional immunoprotection, and reduce infection, death, and hospitalisation times [178]. Indeed, animal studies have shown that breastfeeding confers significant protective functions against necrotising enterocolitis [215], which could be mediated by HM stem cells, immune cells, and other HM components[178]. Further to the preterm infant, HM stem cells may provide medical benefits for infants with genetic diseases or life-threatening conditions and adults [172]. Regenerative medicine is a rapidly developing field that is researching the therapeutic application of the properties of stem cells with multilineage potential. With the recent discovery of induced pluripotent stem cells (iPSCs), i.e., somatic cells that are artificially modified at the gene expression level to display stem cell properties, new horizons have opened for their transplantation into diseased host tissues to facilitate tissue regeneration and restore function[216], [217].

However, many barriers still remain before the iPSC technology can be routinely and safely implemented in the clinical setting. This includes producing genetically identical cells that maintain pluripotency over multiple passages, and that can be reliably differentiated in vitro and in vivo and transplanted into the patient without the risk of cancer or teratoma formation [218]. Immunogenicity of iPSCs (even with syngeneic cell transplants), incomplete iPSC transformation and differentiation, and retained epigenetic memory of transformed cells are still major issues that need to be addressed before iPSC technology can be realistically considered for clinical research [219], [220], [221]. The main current advantages of iPSC technology relate to informing laboratory research, rather than to clinical use. More recently, it has become apparent that studies in pluripotent cells with potential clinical promise need not be limited to iPSCs; stem cells with pluripotent features exist in the adult body, typically providing regeneration/repair cues and facilitating homeostasis in tissues with a high cell turnover. Among these are HM stem cells that possess pluripotent features, non-tumorigenic characteristics, and a natural survival, integration, and tolerance in the offspring. Together, this suggests that they may prove to be excellent candidates for stem cell therapies in infants and/or adults [1] $]$. 
Human milk is one of the most complex live biofluids in existence, offering a myriad of benefits for both mother and infant. A multitude of molecules in HM are only just being identified and their functions elucidated. Greater knowledge will open up the possibility of manipulation of HM components that are critical for the most fragile infants. It will enable the field of lactation diagnostics to develop, providing a much-needed service for lactating women experiencing breastfeeding dysfunction and breast pathologies. Recent research has indicated that human milk also offers the promise of new therapeutic applications for humanity in the future.

\section{Key Points}

- Human milk contains macronutrients, micronutrients, bioactive molecules, cells, and microbiota, making it a living fluid that readily adapts to individual infant needs and provides nutrition, protection, and developmental signals for the infant

- Colostrum albeit low in quantity is highly valuable as it delivers a concentrated dose of immune and bioactive factors that protect the newborn infant in its initial days of life

- Fresh mother's own milk is recommended whenever possible because freezing or pasteurising, will destroy its bioactive components resulting in some loss of benefits

- Human milk is one of the most complex biofluids in existence and is optimally adapted within each mother/infant dyad thus cannot be reproduced in bovine derived formula 


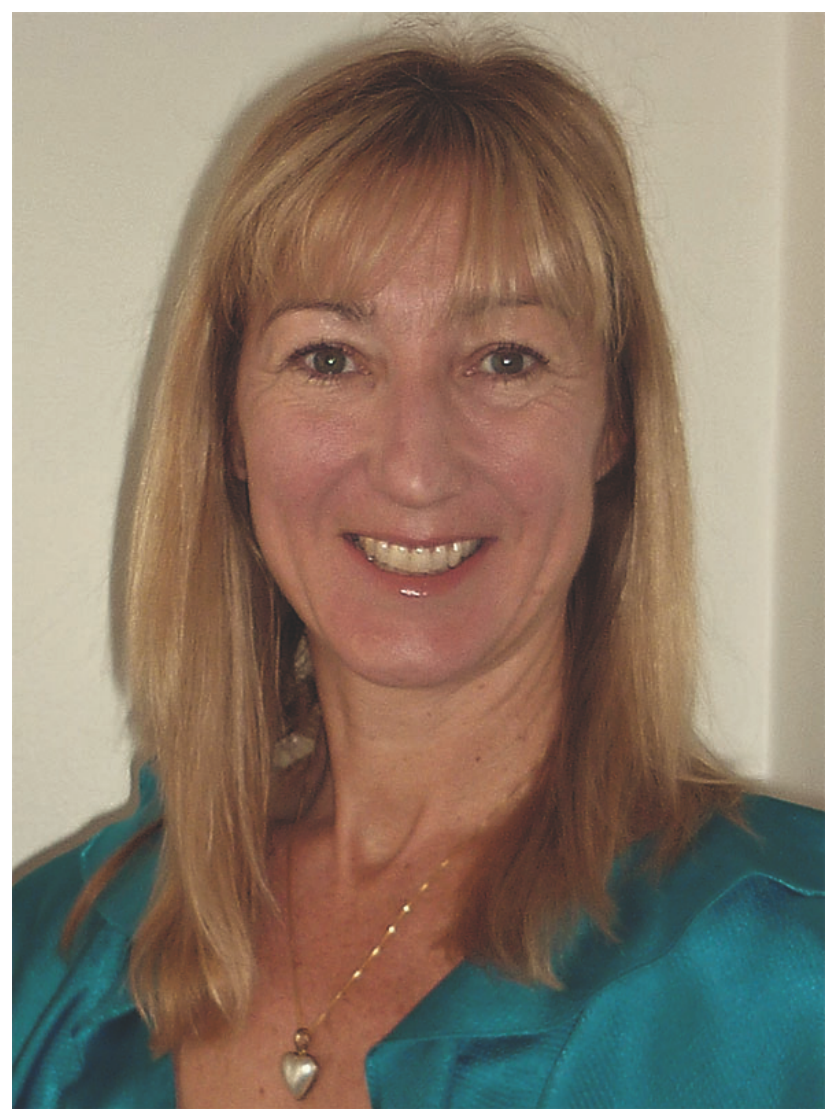

Associate Professor Donna Geddes, PhD, Post Grad Dip (Sci), DMU is an Associate Professor at The University of Western Australia, where she carries out both basic and applied research into human lactation. She has a broad range of research interests, in particular utilising her ultrasound imaging skills to assess the lactating breast

(anatomy, milk ejection and blood flow) as well as the term and preterm infant

(suckswallow-breathe, gastric emptying and body composition). Her most recent work investigates the effect of milk composition on the physiology of the infant. 


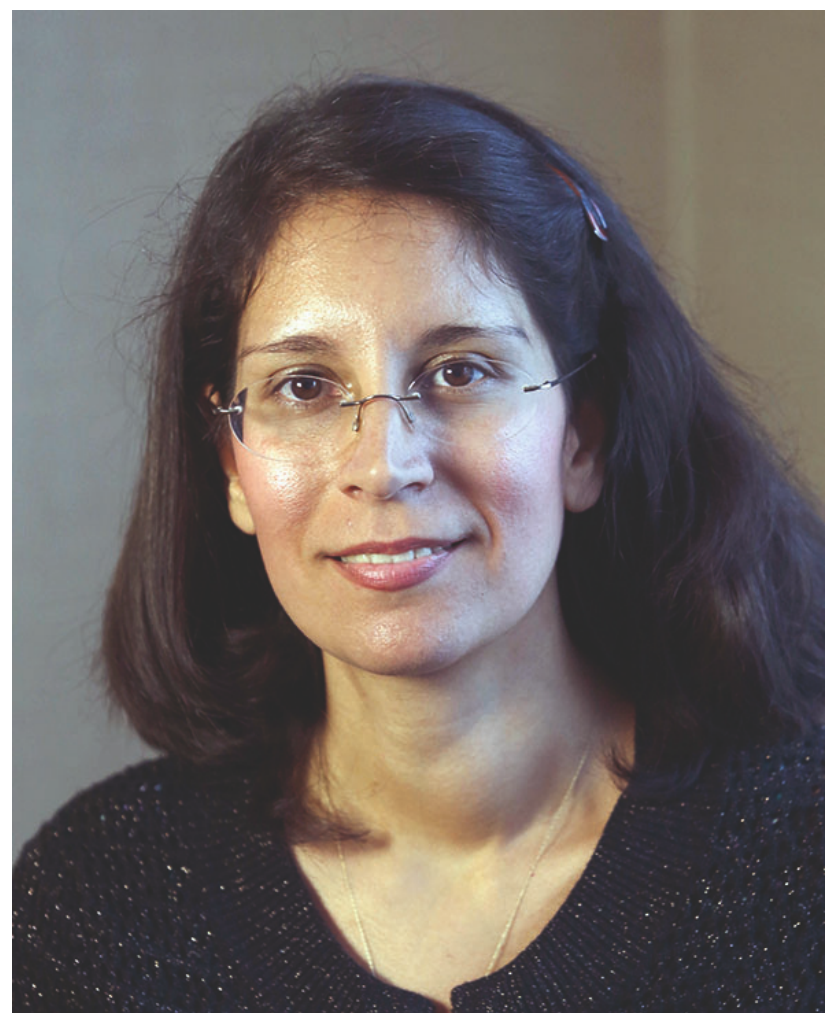

Foteini Kakulas (formerly Hassiotou) PhD, BSc is a Research Fellow at The University of Western Australia. She completed a Biology degree and two PhDs at The University of Western Australia. She has led the Cell Biology Team of the Hartmann Group, where her research is both basic and applied, concentrating on the maternal cells present in breast milk, their involvement in health and disease, and their use as tools to understand the biology of the mammary gland and breastfeeding. Her findings have been widely recognised, with awards on

breast milk stem cells and their transfer to the infant using animal models.

\section{Acknowledgements}

We would like to gratefully acknowledge Mohamed Alsaweed for his development of figure 3 and $\mathrm{Dr}$ Melvin Gay for his contribution to the metabolomic section of the report.

\section{Citations}

[1] McManaman JL, Neville MC. Mammary Physiology and Milk Secretion. Adv Drug Deliv Rev. 2003; 55:629-641 
[2] Jensen RG. Lipids in Human Milk. Lipids 1999; 34:1243-1271

[3] Kent JC, Mitoulas LR, Cregan MD, et al. Volume andFrequency of Breastfeedings and Fat Content ofBreast Milk throughout the Day. Pediatrics. 2006;117: e387-395

[4] Daly SE, Di Rosso A, Owens RA, et al. Degree of Breast Emptying Explains Changes in the Fat Content, but not Fatty Acid Composition, of Human Milk. Exp Physiol. 1993; 78: 741-755

[5] Hassiotou F, Hepworth AR, Williams TM, et al. Breastmilk Cell and Fat Contents Respond Similarly to Removal of Breastmilk by the Infant. PLoS One.2013c; 8: e78232

[6] Emmett PM, Rogers IS. Properties of Human Milk and Their Relationship with Maternal Nutrition. Early Hum Dev. 1997; 49 Suppl: S7-28

[7] Hamosh M. Lipid Metabolism in Pediatric Nutrition.Pediatr Clin North Am. 1995; 42: 839-859

[8] Innis SM. Dietary Triacylglycerol Structure and ItsRole in Infant Nutrition. Adv Nutr. 2011; 2: 275-283

[9] Martin JC, Bougnoux P, Antoine JM, et al. Triacylglycerol Structure of Human Colostrum and Mature Milk. Lipids. 1993; 28: 637-643

[10] Innis SM. Polyunsaturated Fatty Acids in HumanMilk: An Essential Role in Infant Development. Adv Exp Med Biol. 2004; 554: 27-43

[11] Nasser R, Stephen AM, Goh YK, et al. The Effect of a Controlled Manipulation of Maternal Dietary Fat Intake on Medium and Long Chain Fatty Acids in Human Breast Milk in Saskatoon, Canada. Int Breastfeed J. 2010; 5: 3

[12] Ribeiro P, Carvalho FD, Abreu Ade A, et al. Effect ofFish Oil Supplementation in Pregnancy on the FattyAcid Composition of Erythrocyte Phospholipids andBreast Milk Lipids. Int J Food Sci Nutr. 2012; 63: 36-40

[13] Innis SM. Human Milk: Maternal Dietary Lipids andInfant Development Proc Nutr Soc. 2007; 66: 397-404

[14] Straarup EM, Lauritzen L, Faerk J, et al. The Stereospecific Triacylglycerol Structures and Fatty AcidProfiles of Human Milk and Infant Formulas. J Pediatr Gastroenterol Nutr. 2006; 42: 293-299

[15] Agostoni C, Caroli M. Role of Fats in the First Two Years of Life as Related to Later Development ofNCDs. Nutr Metab Cardiovasc Dis. 2012b; 2: 775-780 
[16] Agostoni C, Caroli M. Role of Fats in the First Two Years of Life as Related to Later Development ofNCDs. Nutr Metab Cardiovasc Dis. 2012a; 22: 775-780

[17] Fleith M, Clandinin MT. Dietary PUFA for Preterm and Term Infants: Review of Clinical Studies Crit Rev Food Sci Nutr. 2005; 45: 205-229

[18] Tanaka K, Hosozawa M, Kudo N, et al. The PilotStudy: Sphingomyelin-Fortified Milk Has a Positive Association with the Neurobehavioural Development of Very Low Birth Weight Infants during Infancy, Randomized Control Trial. Brain Dev. 2013;35: 45-52

[19] Newburg D. Innate Immunity and Human Milk. JNutr. 2005; 135: 1308-1312

[20] Welsh J, Arsenakis M, May JT. Effect on Semliki Forest Virus and Coxsackievirus B4 of Lipids Common to Human Milk. J Food Safety. 1981; 3: 99-107

[21] Thormar H, Isaacs CE, Brown HR, et al. Inactivation of Enveloped Viruses and Killing of Cells by Fatty Acids and Monoglycerides. Antimicrob Agents Chemother. 1987; 31: 27-31

[22] Villamor E, Koulinska IN, Furtado J, et al. Long-Chain n-6 Polyunsaturated Fatty Acids in Breast Milk Decrease the Risk of HIV Transmission through Breastfeeding. Am J Clin Nutr. 2007; 86: 682-689

[23] Hambraeus L, Lonnerdal B, Forsum E, et al. Nitrogen and Protein Components of Human Milk. Acta Paediatr Scand. 1978; 67: 561-565

[24] Atkinson SH, Lonnerdal B. Nonprotein Nitrogen Fractions of Human Milk. In: Jensen R (ed). Handbook of Milk Composition. San Deigo, USA: Academic Press, 1995b; 369-387

[25] Yu VY. Scientific Rationale and Benefits of Nucleotide Supplementation of Infant Formula. J Paediat Child Health. 2002; 38: 543-549

[26] Carver JD. Dietary Nucleotides: Cellular Immune, Intestinal and Hepatic System Effects. J Nutr. 1994;124: 144S-148S

[27] Andreas NJ, Kampmann B, Mehring Le-Doare K. Human breast milk: A Review on its Composition and Bioactivity. Early Hum Dev. 2015b; 91: 629-635

[28] Chesney RW, Helms RA, Christensen M, et al. The Role of Taurine in Infant Nutrition. Adv Exp Med Biol. 1998; 442: 463-476

[29] Schack-Nielsen L and Michaelsen KF. Advances in our Understanding of the Biology of Human Milk and its Effects on the Offspring. J Nutr. 2007; 137:503S-510S 
[30] Goodman JW, Hodgson GS. Evidence for Stem Cells in the Peripheral Blood of Mice. Blood. 1962; 19:702-714

[31] Lönnerdal B, Atkinson SA. Human Milk Proteins. In:Jensen UG (ed). Handbook of Milk Composition. San Diego: Academic Press; 1995

[32] Hassiotou F, Geddes DT. Programming of Appetite Control during Breastfeeding as a Preventative Strategy against the Obesity Epidemic. J Hum Lact.2014; 30: 136-142

[33] Martin FP, Moco S, Montoliu I, et al. Impact of Breast-Feeding and High- And Low-Protein Formula on the Metabolism and Growth of Infants from Overweight and Obese Mothers. Pediatr Res. 2014;75: 535-543

[34] Institute of Medicine. Dietary Reference Intakes for Energy, Carbohydrate, Fiber, Fat, Fatty Acids, Cholesterol, Protein and Amino Acids. Washington, DC: The National Academies Press. 2005

[35] Michaelsen KF, Greer FR. Protein Needs Early in Life and Long-Term Health. Am J Clin Nutr. 2014; 99(suppl): 18S-22S

[36] Michaelsen KF, Larnkjaer A, Molgaard C. Amount and Quality of Dietary Proteins during the First Two Years of Life in Relation to NCD Risk in Adulthood. Nutr Metab Cardiovasc Dis. 2012; 22: 781786

[37] Koletzko B, von Kries R, Closa R, et al. Lower Protein in Infant Formula Is Associated with Lower Weight up to Age 2 Y: A Randomized Clinical Trial. Am J Clin Nutr 2009; 89: 1836-1845

[38] Socha P, Grote V, Gruszfeld D, et al. Milk Protein Intake, the Metabolic-Endocrine Response, and Growth in Infancy: Data from a Randomized ClinicalTrial. Am J Clin Nutr. 2011; 94 (suppl): 1776S$1784 \mathrm{~S}$

[39] Czank C. Human Milk Composition - Nitrogen and Energy Content. In: Hale TW and Hartmann PE(eds). Textbook of Human Lactation. Amarillo, Texas: Hale Publishing, LP; 2007: 75-88

[40] Bounous G, Kongshavn PA, Taveroff A, et al. Evolutionary Traits in Human Milk Proteins. Med hypotheses. 1988; 27: 133-140

[41] Kunz C, Lönnerdal B. Re-Evaluation of the whey Protein/Casein Ratio of Human Milk. Acta Pædiatr.1992; 81: 107-112

[42] Ewer AK, Durbin GM, Morgan ME, et al. Gastric Emptying in Preterm Infants. Arch Dis Child Fetal Neonatal Ed. 1994; 71: F24-27 
[43] Cavell B. Gastric Emptying in Infants Fed HumanMilk or Infant Formula. Acta Paediatr Scand. 1981;70: 639-641

[44] Van den Driessche M, Peeters K, Marien P, et al. Gastric Emptying in Formula-Fed and BreastFed Infants Measured with the 13C-Octanoic Acid Breath Test. J Pediatr Gastroenterol Nutr. 1999; 29: 46-51

[45] Davies DT, Holt C, Christie WW. The Composition of Milk. In: Mepham TB (ed). Biochemistry of lactation. Amsterdam: Elsevier; 1983: 71-117

[46] Newton ER. Breastmilk: The Gold Standard. Clin Obstet Gynecol. 2004; 47: 632-642

[47] Mange A, Bellet V, Tuaillon E, et al. Comprehensive Proteomic Analysis of the Human Milk Proteome:Contribution of Protein Fractionation. J ChromatogrB Analyt Technol Biomed Life Sci. 2008; 876: 252- 256

[48] D’Alessandro A, Scaloni A, Zolla L. Human Milk Proteins: An Interactomics and Updated Functional Overview. J Proteome Res. 2010; 9: 3339-3373

[49] Lonnerdal B, Iyer S. Lactoferrin: Molecular Structure and Biological Function. Ann Rev Nutr. $1995 ; 15: 93-110$

[50] Kawakami H, Lonnerdal B. Isolation and Function of a Receptor for Human Lactoferrin in Human Fetal Intestinal Brush-Border Membranes. Am J Physiol.1991; 261: G841-846

[51] Suzuki YA, Lonnerdal B. Characterization of Mammalian Receptors for Lactoferrin. Biochem Cell Biol.2002; 80: 75-80

[52] Chierici R, Sawatzki G, Tamisari L, et al. Supplementation of an Adapted Formula with Bovine Lactoferrin. 2. Effects on serum iron, ferritin and zinc levels. Acta Paediatr. 1992; 81: 475-479

[53] Johnston WH, Ashley C, Yeiser M, et al. Growth and Tolerance of Formula with Lactoferrin in Infants through One Year of Age: Double-Blind, Randomized, Controlled Trial. BMC Pediatr. 2015; 15: 173

[54] Davidson LA, Lonnerdal B. Specific Binding of Lactoferrin to Brush-Border Membrane: Ontogeny and Effect of Glycan Chain. Am J Physiol. 1988; 254: G580-585

[55] Arnold RR, Brewer M, Gauthier JJ. Bactericidal Activity of Human Lactoferrin: Sensitivity of a Variety of Microorganisms. Infect Immun. 1980; 28: 893-898 
[56] Tomita M, Bellamy W, Takase M, et al. Potent Antibacterial Peptides Generated by Pepsin Digestion of Bovine Lactoferrin. J Dairy Sci. 1991; 74: 4137-4142

[57] Gifford JL, Hunter HN, Vogel HJ. Lactoferricin: A Lactoferrin-Derived Peptide with Antimicrobial, Antiviral, Antitumor and Immunological Properties. Cell Mole Life Sci. 2005; 62: 25882598

[58] Chipman DM and Sharon N. Mechanism of Lysozyme Action. Science. 1969; 165: 454-465

[59] Ellison RT, 3rd, Giehl TJ. Killing of Gram-Negative Bacteria by Lactoferrin and Lysozyme. J Clin Invest.1991; 88: 1080-1091

[60] Leon-Sicairos N, Lopez-Soto F, Reyes-Lopez M, et al. Amoebicidal Activity of Milk, ApoLactoferrin, sIgA and Lysozyme. Clin Med Res. 2006; 4: 106-113

[61] Lee-Huang S, Maiorov V, Huang PL, et al. Structural and Functional Modeling of Human Lysozyme Reveals a Unique Nonapeptide, HL9, with Anti-HIV Activity. Biochemistry. 2005; 44: 46484655

[62] Minami J, Odamaki T, Hashikura N, et al. Lysozyme in Breast Milk Is a Selection Factor for Bifidobacterial Colonisation in the Infant Intestine. Benef Microbes. 2015; Oct 27: 1-8

[63] Oliver WT, Wells JE. Lysozyme as an Alternative toGrowth Promoting Antibiotics in Swine Production. J Anim Sci Biotechnol. 2015; 6: 35

[64] Braun $\mathrm{OH}$, Sandkuhler H. Relationships between Lysozyme Concentration of Human Milk, Bacteriologic Content, and Weight Gain of Premature Infants. J Pediatr Gastroenterol Nutr. 1985; 4: 583-586

[65] Christen L, Lai CT, Hartmann B, et al. The effect of UV-C Pasteurization on Bacteriostatic Properties and Immunological Proteins of Donor Human Milk. PLoS One. 2013a; 8: e85867

[66] Atkinson SH, Lonnerdal B. Nitrogenous Components of Milk. In: Jensen R (ed). Handbook of Milk Composition. San Diego, USA: Academic Press; 1995a:351-368

[67] Brew K, Hill RL. Lactose Biosynthesis. Rev PhysiolBiochem Pharmacol. 1975; 72: 105-158

[68] Ren J, Stuart DI, Acharya KR. Alpha-Lactalbumin Possesses a Distinct Zinc Binding Site. J Biolog Chem. 1993; 268: 19292-19298

[69] Lonnerdal B, Glazier C. Calcium Binding by AlphaLactalbumin in Human Milk and Bovine Milk. J Nutr.1985; 115: 1209-1216 
[70] Kelleher SL, Chatterton D, Nielsen K, et al. Glycomacropeptide and Alpha-Lactalbumin Supplementation of Infant Formula Affects Growth and Nutritional Status in Infant Rhesus Monkeys. Am J Clin Nutr.2003; 77: 1261-1268

[71] Forsum E. Nutritional Evaluation of Whey ProteinConcentrates and their Fractions. J Dairy Sci. 1974;57: 665-670

[72] Lonnerdal B. Nutritional and Physiologic Significance of Human Milk Proteins. Am J Clin Nutr. 2003; 77:1537S-1543S

[73] Chatterton DE, Nguyen DN, Bering SB, et al. Anti-Inflammatory Mechanisms of Bioactive Milk Proteins in the Intestine of Newborns. Int J Biochem Cell Biol.2013; 45: 1730-1747

[74] Goldman AS, Goldblum RM. Defense Agents in Milk. In: Jensen R (ed). Handbook of Milk Composition.San Diego, USA: Academic Press; 1995: 727-745

[75] Lewis-Jones DI, Lewis-Jones MS, Connolly RC et al. Sequential changes in the antimicrobial protein concentrations in human milk during lactation and its relevance to banked human milk. Pediatr. Res.1985; 19: 561-565

[76] Goldblum RM, Ahlstedt S, Carlsson B, et al. Antibody-Forming Cells in Human Colostrum after Oral Immunisation. Nature. 1975; 257: 797-798

[77] Hanson LA, Korotkova M. The Role of Breastfeeding in Prevention of Neonatal Infection. Semin Neonatol. 2002; 7: 275-281

[78] Arnold JN, Wormald MR, Sim RB, et al. The Impact of Glycosylation on the Biological Function and Structure of Human Immunoglobulins. Ann Rev Immunol 2007; 25: 21-50

[79] Blackberg L, Hernell O. Further Characterization of the Bile Salt-Stimulated Lipase in Human Milk. FEBS Lett. 1983; 157: 337-341

[80] Tully DB, Jones F, Tully MR. Donor Milk: What's in It and What's Not. J Hum Lact. 2001; 17: 152155

[81] Andersson Y, Savman K, Blackberg L, et al. Pasteurization of Mother's Own Milk Reduces Fat Absorption and Growth in Preterm Infants. Acta Paediatr. 2007;96: 1445-1449

[82] Christen L, Lai CT, Hartmann B, et al. Ultraviolet-CIrradiation: A Novel Pasteurization Method for Donor Human Milk. PLoS One. 2013b; 8: e68120 
[83] da Silva AP, Ellen RP, Sorensen ES, et al. Osteopontin Attenuation of Dextran Sulfate SodiumInduced Colitis in Mice. Lab Invest. 2009; 89: 1169-1181

[84] Donovan SM, Monaco MH, Drnevich J, et al. Bovine Osteopontin Modifies the Intestinal Transcriptome of Formula-Fed Infant Rhesus Monkeys to Be More Similar to Those That Were Breastfed. J Nutr. 2014a;144: 1910-1919

[85] Lonnerdal B, Kvistgaard AS, Peerson JM, et al. Growth, Nutrition and Cytokine Response of BreastFed Infants and Infants Fed Formula with Added Bovine Osteopontin. J Pediatr Gastroenterol Nutr.2016; 62: 650-657

[86] Lindberg T, Ohlsson K, Westrom B. Protease Inhibitors and their Relation to Protease Activity in Human Milk. Pediatr Res. 1982; 16: 479-483

[87] Mellersh A, Clark A, Hafiz S. Inhibition of Neisseria Gonorrhoeae by Normal Human Saliva. Br J Vener Dis. 1979; 55: 20-23.

[88] Sandberg DP, Begley JA, Hall CA. The Content, Binding, and Forms of Vitamin B12 in Milk. Am J Clin Nutr. 1981; 34: 1717-1724

[89] Adkins Y, Lonnerdal B. Mechanisms of Vitamin B(12) Absorption in Breast-Fed Infants. J Pediatr Gastroenterol Nutr. 2002; 35: 192-198

[90] Chollet-Hinton LS, Stuebe AM, Casbas-Hernandez P, et al. Temporal Trends in the Inflammatory CytokineProfile of Human Breastmilk. Breastfeed Med. 2014;9: 530-537

[91] Fields DA, Demerath EW. Relationship of Insulin,Glucose, Leptin, IL-6 and TNF-alpha in Human Breast Milk with Infant Growth and Body Composition. Pediatr Obes. 2012; 7: 304-312

[92] Donovan SM, Odle J. Growth Factors in Milk As Mediators of Infant Development. Ann Rev Nutr. 1994;14: 147-167

[93] Frost BL, Jilling T, Lapin B, et al. Maternal Breast Milk Transforming Growth Factor-Beta and Feeding Intolerance in Preterm Infants. Pediatr Res. 2014; 76:386-393

[94] Maheshwari A, Kelly DR, Nicola T, et al. TGF-Beta2Suppresses Macrophage Cytokine Production andMucosal Inflammatory Responses in the Developing Intestine. Gastroenterology. 2011; 140: $242-253$

[95] Groer M, Duffy A, Morse S, et al. Cytokines, Chemokines, and Growth Factors in Banked Human Donor Milk for Preterm Infants. J Hum Lact. 2014; 30: 317-323 
[96] Neville MC. Physiology of Lactation. Clin Perinatol.1999; 26: 251-279

[97] Kulski JK, Hartmann PE. Changes in Human MilkComposition during the Initiation of Lactation. Aust J Exp Biol Med Sci. 1981; 59: 101-114

[98] Newburg DS, Neubauer SH. Carbohydrates in Milks: Analysis, Quantities and Significance. In: Jensen RG(ed). Handbook of Milk Composition. San Diego, USA: Academic Press; 1995

[99] German JB, Freeman SL, Lebrilla CB, et al. Human Milk Oligosaccharides: Evolution, Structures and Bioselectivity as Substrates for Intestinal Bacteria. Nestle NutrWorkshop Ser Pediatr Program. 2008; 62:205-218; discussion 218-222

[100] Bode L. Human Milk Oligosaccharides: Every Baby Needs a Sugar Mama. Glycobiology. 2012; 22:1147-1162

[101] Newburg DS. Glycobiology of Human Milk. Biochemistry (Mosc). 2013; 78: 771-785

[102] Alderete TL, Autran C, Brekke BE, et al. Associations between Human Milk Oligosaccharides and InfantBody Composition in the First 6 Mo of Life. Am J Clin Nutr. 2015; 102: 1381-1388

[103] Wang B, McVeagh P, Petocz P, et al. Brain Ganglioside and Glycoprotein Sialic Acid in Breastfed Compared with Formula-Fed Infants. Am J Clin Nutr.2003; 78: 1024-1029

[104] Kuhn L, Kim HY, Hsiao L, et al. Oligosaccharide Composition of Breast Milk Influences Survival of Uninfected Children Born to HIV-Infected Mothers in Lusaka, Zambia. J Nutr. 2015; 145: 6672

[105] Jantscher-Krenn E, Lauwaet T, Bliss LA, et al. Human Milk Oligosaccharides Reduce Entamoeba Histolytica Attachment and Cytotoxicity in Vitro. Br J Nutr.2012; 108: 1839-1846

[106] Bode L. The Functional Biology of Human Milk Oligosaccharides. Early Hum Dev. 2015; 91: 619622

[107] Gonia S, Tuepker M, Heisel T, et al. Human Milk Oligosaccharides Inhibit Candida Albicans Invasion ofHuman Premature Intestinal Epithelial Cells. J Nutr.2015; 145: 1992-1998

[108] Zivkovic AM, German JB, Lebrilla CB, et al. Human Milk Glycobiome and Its Impact on the Infant Gastrointestinal Microbiota. Proc Natl Acad Sci USA.2011; 108 Suppl 1: 4653-4658

[109] Picciano MF. Nutrient Composition of Human Milk. Pediatr Clin North Am. 2001; 48: 53-67

[110] Allen LH. Multiple Micronutrients in Pregnancy andLactation: An Overview. The Am J Clin Nutr. 2005;81: 1206S-1212S 
[111] Ala-Houhala M, Koskinen T, Parviainen MT, et al. 25Hydroxyvitamin D and Vitamin D in Human Milk: Effects of Supplementation and Season. Am J Clin Nutr. 1988; 48: 1057-1060

[112] Greer FR, Hollis BW, Cripps DJ, et al. Effects of Maternal Ultraviolet B Irradiation on Vitamin D Content of Human Milk. J Pediatr. 1984; 105: 431-433

[113] Specker BL, Tsang RC, Hollis BW. Effect of Race and Diet on Human-Milk Vitamin D and 25Hydroxyvitamin D. Am J Dis Child. 1985; 139: 1134-1137

[114] Pugliese MT, Blumberg DL, Hludzinski J, et al. Nutritional Rickets in Suburbia. J Am Coll Nutr. 1998; 17: 637-641

[115] Thiele DK, Senti JL, Anderson CM. Maternal VitaminD Supplementation to Meet the Needs of the Breastfed Infant: A Systematic Review. J Hum Lact.2013; 29: 163-170

[116] Wagner CL, Greer FR. Prevention of Rickets and Vitamin D Deficiency in Infants, Children, and Adolescents. Pediatrics. 2008; 122: 1142-1152

[117] Georgieff MK, Wewerka SW, Nelson CA, et al. IronStatus at 9 Months of Infants with Low Iron Stores at Birth. J Pediatr. 2002; 141: 405-409

[118] Krebs NF, Sherlock LG, Westcott J, et al. Effects ofDifferent Complementary Feeding Regimens on Iron Status and Enteric Microbiota in Breastfed Infants. J Pediatr. 2013; 163: 416-423

[119] Friel JK, Aziz K, Andrews WL, et al. A double-Masked, Randomized Control Trial of Iron Supplementation in Early Inf ancy in Healthy Term Breast-Fed Infants. JPediatr. 2003; 143: 582-586

[120] Baker RD, Greer FR. Diagnosis and Prevention of Iron Deficiency and Iron-Deficiency Anemia in Infants and Young Children (0-3 Years of Age). Pediatrics. 2010; 126: 1040-1050

[121] Gibson RS. A Historical Review of Progress in the Assessment of Dietary Zinc Intake as an Indicator of Population Zinc Status. Adv Nutr. 2012; 3: 772-782

[122] Brown KH, Rivera JA, Bhutta Z, et al. International Zinc Nutrition Consultative Group (IZiNCG) Technical Document \#1. Assessment of the risk of zinc deficiency in populations and options for its control. Food Nutr Bull. 2004; 25: S99-203

[123] Krebs NF, Miller LV, Hambidge KM. Zinc Deficiency in Infants and Children: A Review of its Complex and Synergistic Interactions. Paediatr Int Child Health.2014; 34: 279-288

[124] Rautava S, Luoto R, Salminen S, et al. Microbial Contact during Pregnancy, Intestinal Colonization and Human Disease. Nat Rev Gastroenterol Hepatol.2012; 9: 565-576 
[125] Donovan SM, Wang M, Monaco MH, et al. Noninvasive Molecular Fingerprinting of HostMicrobiome Interactions in Neonates. FEBS Lett. 2014b; 588:4112-4119

[126] Bezirtzoglou E, Tsiotsias A, Welling GW. Microbiota Profile in Feces of Breast- and Formula-Fed Newborns by Using Fluorescence in Situ Hybridization(FISH). Anaerobe. 2011; 17: 478-482

[127] Hunt KM, Foster JA, Forney LJ, et al. Characterization of the Diversity and Temporal Stability of Bacterial Communities in Human Milk. PLoS One 2011; 6: e21313

[128] Turnbaugh PJ, Ridaura VK, Faith JJ, et al. The Effect of Diet on the Human Gut Microbiome: A Metagenomic Analysis in Humanized Gnotobiotic Mice. Sci Transl Med. 2009; 1: 6ra14

[129] Cabrera-Rubio R, Collado MC, Laitinen K, et al. The Human Milk Microbiome Changes over Lactation and Is Shaped by Maternal Weight and Mode of Delivery. Am J Clin Nutr. 2012b 96: 544-551

[130] Azad MB, Konya T, Persaud RR, et al. Impact of Maternal Intrapartum Antibiotics, Method of Birth and Breastfeeding on Gut Microbiota during the First Year of Life: A Prospective Cohort Study. BJOG.2016; 123: 983-993

[131] Fouhy F, Ross RP, Fitzgerald GF, et al. Composition of the Early Intestinal Microbiota: Knowledge, Knowledge Gaps and the Use of High-Throughput Sequencing to Address these Gaps. Gut Microbes. 2012; 3: 203-220

[132] Tanaka S, Kobayashi T, Songjinda P, et al. Influence of Antibiotic Exposure in the Early Postnatal Period on the Development of Intestinal Microbiota. FEMS Immunol Med Microbiol. 2009; 56: $80-87$

[133] Soto A, Martin V, Jimenez E, et al. Lactobacilli andBifidobacteria in Human Breast Milk: Influence of Antibiotherapy and Other Host and Clinical Factors. J Pediatr Gastroenterol Nutr. 2014; 59: $78-88$

[134] Yu Z, Chen C, McCoy JM, Liu B, et al. The PrincipleFucosylated Oligosaccharides of Human Milk Exhibit Prebiotic Properties on Cultured Infant Microbiota. 16th International Conference of the Society for Research into Human Milk and Lactation. Trieste, Italy;2012

[135] Rogier EW, Frantz AL, Bruno ME, et al. Secretory Antibodies in Breast Milk Promote LongTerm Intestinal Homeostasis by Regulating the Gut Microbiota and Host Gene Expression. Proc Natl Acad Sci USA.2014; 111: 3074-3079

[136] Fernandez L, Langa S, Martin V, et al. The Human Milk Microbiota: Origin and Potential Roles in Health and Disease. Pharmacol Res. 2013; 69: 1-10 
[137] Woo JG, Martin LJ. Does Breastfeeding Protect Against Childhood Obesity? Moving beyond observational evidence. Curr Obes Rep. 2015; 4: 207-216

[138] Dewey KG, Lonnerdal B. Infant Self-Regulation of Breast Milk Intake. Acta Paediatr Scand 1986; 75:893-898

[139] Li R, Scanlon KS, May A, et al. Bottle-Feeding Practices during Early Infancy and Eating Behaviors at 6 Years of Age. Pediatrics. 2014; 134 Suppl 1: S70-77

[140] Li R, Fein SB, Grummer-Strawn LM. Association of Breastfeeding Intensity and BottleEmptying Behaviors at Early Infancy with Infants' Risk for Excess Weight at Late Infancy. Pediatrics. 2008; 122 Suppl2: S77-84

[141] Savino F, Liguori SA, Fissore MF, et al. Breast MilkHormones and their Protective Effect on Obesity. Int J Pediatr Endocrinol. 2009; 2009: 327505

[142] Maffei HV, Nobrega FJ. Gastric pH and Microflora ofNormal and Diarrhoeic Infants. Gut. 1975; 16: $719-726$

[143] Van Elburg RM, Uil JJ, de Monchy JG, et al. Intestinal Permeability in Pediatric Gastroenterology. Scand J Gastroenterol Suppl. 1992; 194: 19-24

[144] Barrenetxe J, Villaro AC, Guembe L, et al. Distribution of the Long Leptin Receptor Isoform in BrushBorder, Basolateral Membrane, and Cytoplasm ofEnterocytes. Gut. 2002; 50: 797-802

[145] Chowanadisai W and Lonnerdal B. Alpha(1)-Antitrypsin and Antichymotrypsin in Human Milk: Origin, Concentrations, and Stability. Am J Clin Nutr.2002; 76: 828-833

[146] Wada Y, Lonnerdal B. Bioactive Peptides Derived from Human Milk Proteins-Mechanisms of Action. J Nutr Biochem. 2014; 25: 503-514

[147] Klein S, Coppack SW, Mohamed-Ali V, et al. Adipose Tissue Leptin Production and Plasma Leptin Kinetics in Humans. Diabetes 1996; 45: 984-987

[148] Cinti S, Matteis RD, Pico C, et al. Secretory Granules of Endocrine and Chief Cells of Human Stomach Mucosa Contain Leptin. Int J Obes Relat Metab Disord.2000; 24: 789-793

[149] Masuzaki H, Ogawa Y, Sagawa N, et al. Nonadipose Tissue Production of Leptin: Leptin as a Novel Placenta-Derived Hormone in Humans. Nat Med. 1997;3: 1029-1033

[150] Hassiotou F, Savigni D, Hartmann PE, et al. Appetite Hormones Present in Breastmilk Can Be Synthesized by Mammary Cells during Lactation. Bi-annual Conference of International Society for 
Research in Human Milk and Lactation. Charleston, South Carolina, USA, October 2014. 2014c

[151] Hassiotou F, Lai CT, Filgueira L, et al. Mammary CellsSynthesize Insulin during Lactation. FASEB J. 2014b;28

[152] Hassiotou F, Savigni D, Hartmann PE, et al. Mammary Cells Synthesize Appetite Hormones That May Contribute to Breastmilk. FASEB J, 2014d; 28

[153] Quinn EA, Largado F, Borja JB, et al. Maternal Characteristics Associated with Milk Leptin Content in a Sample of Filipino Women and Associations with Infant Weight for Age. J Hum Lact. 2015; 31: 273-281

[154] Weyermann M, Brenner H, Rothenbacher D. Adipokines in Human Milk and Risk of Overweight in early childhood: a prospective cohort study. Epidemiology. 2007; 18: 722-729

[155] Cabrera W, Knapp J. Metabolomics: Metabolites, Metabonomics, and Analytical Technologies, New York: Nova Science Publishers, Inc.; 2011

[156] Dessi A, Cesare Marincola F, Masili A, et al. ClinicalMetabolomics and Nutrition: The New Frontier inNeonatology and Pediatrics. Biomed Res Int. 2014;2014: 981219

[157] Cesare Marincola F, Dessi A, Corbu S, et al. Clinical Impact of Human Breast Milk Metabolomics. Clin Chim Acta. 2015; 451: 103-106

[158] Zhang A, Sun H, Wang P, et al. Recent and Potential Developments of Biofluid Analyses in Metabolomics. J Proteomics. 2012a; 75: 1079-1088

[159] Marincola FC, Noto A, Caboni P, et al. A Metabolomic Study of Preterm Human and Formula Milk by High Resolution NMR and GC/MS Analysis: Preliminary Results. J Matern Fetal Neonatal Med. 2012;25: $62-67$

[160] Longini M, Tataranno ML, Proietti F, et al. A Metabolomic Study of Preterm and Term Human and Formula Milk by Proton MRS Analysis: Preliminary Results. J Matern Fetal Neonatal Med. 2014; 27 Suppl2: $27-33$

[161] Smilowitz JT, O’Sullivan A, Barile D, et al. The Human Milk Metabolome Reveals Diverse Oligosaccharide Profiles. J Nutr. 2013; 143: 1709-1718

[162] Mateos-Vivas M, Rodriguez-Gonzalo E, DominguezAlvarez J, et al. Analysis of Free Nucleotide Monophosphates in Human Milk and Effect of Pasteurisation or High-Pressure Processing on their Contents by Capillary Electrophoresis Coupled to Mass Spectrometry. Food Chem. 2015; 174: 348-355 
[163] Albrecht S, Schols HA, van den Heuvel EG, et al. CELIF-MSn Profiling of Oligosaccharides in Human Milk and Feces of Breast-fed Babies. Electrophoresis2010; 31: 1264-1273

[164] Villasenor A, Garcia-Perez I, Garcia A, et al. BreastMilk Metabolome Characterization in a Single-PhaseExtraction, Multiplatform Analytical Approach. Anal Chem. 2014; 86: 8245-8252

[165] Andreas NJ, Hyde MJ, Gomez-Romero M, et al. Multiplatform Characterization of Dynamic Changes in Breast Milk during Lactation. Electrophoresis.2015a; May 11. doi: 10.1002/elps.201500011. [Epub ahead of print]

[166] Newburg DS, Morelli L. Human Milk and Infant Intestinal Mucosal Glycans Guide Succession of the Neonatal Intestinal Microbiota. Pediatr Res. 2015;77: 115-120

[167] Cabrera-Rubio R, Collado MC, Laitinen K, et al. The Human Milk Microbiome Changes over Lactation and Is Shaped by Maternal Weight and Mode of Delivery. Am J Clin Nutr. 2012a; 96: 544-551

[168] Donné A. Du lait et en particulier de celui de nourrices, considéré sous le rapport de ses bonnes et de ses mavaises qualités nitritives et de ses altérations. Paris, Rue de Condé: no 15; Les Libraires de Médecine, Chevalier, Palais Royal, no 163; 1837

[169] Henle J. Allgemeine Anatomie. 2 Aufl., L. Voss, Leipzig, Germany 1841

[170] Holmquist DG, Papanicolaou GN. The Exfoliative Cytology of the Mammary Gland during Pregnancy and Lactation. Ann N Y Acad Sci. 1956; 63: 1422- 1435

[171] Hassiotou F, Beltran A, Chetwynd E, et al. Breastmilk Is a Novel Source of Stem Cells with Multilineage Differentiation Potential. Stem cells. 2012a; 30: 2164-2174

[172] Hassiotou F, Geddes DT, Hartmann PE. Cells in Human Milk: State of the Science. J Hum Lact. 2013a;29: 171-182

[173] Hassiotou F, Hartmann PE. At the Dawn of a New Discovery: The Potential of Breastmilk Stem Cells. Adv Nutr. 2014; 5: 770-778

[174] Hassiotou F, Hepworth AR, Metzger P, et al. Maternal and Infant Infections Stimulate a Rapid Leukocyte Response in Breastmilk. Clin Translat Immunol. 2013b; 2: e3

[175] Hassiotou F, Geddes D. Immune Cell-Mediated Protection of the Mammary Gland and the Infant during Breastfeeding. Adv Nutr. 2015; 6: 267-275

[176] Hassiotou F, Hepworth AR, Williams TM, et al. Breastmilk cell and fat contents respond similarly to removal of breast milk by the infant. PLoS One.2013d; 8: e78232 
[177] Riskin A, Almog M, Peri R, et al. Changes in Immunomodulatory Constituents of Human Milk in Response to Active Infection in the Nursing Infant. Pediatr Res. 2012; 71: 220-225

[178] Kakulas F. Breast Milk: A Source Of Stem Cells and Protective Cells for the Infant. Infant. 2015; 11:187-191

[179] Lu L, Li Y, Du MJ, et al. Characterization of a Self-Renewing and Multi-Potent Cell Population Isolated from Human Minor Salivary Glands. Sci Rep. 2015;5: 10106

[180] Wu S, Liu Y, Bharadwaj S, et al. Human Urine-Derived Stem Cells Seeded in a Modified 3d Porous Small Intestinal Submucosa Scaffold for Urethral Tissue Engineering. Biomaterials. 2011; 32: $1317-1326$

[181] Hassiotou F, Beltran A, Chetwynd E, et al. Breastmilk Is a Novel Source of Stem Cells with Multi-Lineage Differentiation Potential. Stem Cells. 2012b; 30:2164-2174

[182] Hassiotou F, Heath B, Ocal O, et al. Breastmilk Stem Cell Transfer from Mother to Neonatal Organs. FASEB J. 2014a; 28

[183] Barinaga M. Cells Exchanged during Pregnancy Live on. Science. 2002; 296: 2169-2172

[184] Dutta P, Burlingham WJ. Stem Cell Microchimerism and Tolerance to Non-Inherited Maternal Antigens. Chimerism. 2010; 1: 2-10

[185] Jain L, Vidyasagar D, Xanthou M, et al. In Vivo Distribution of Human Milk Leucocytes after Ingestion byNewborn Baboons. Arch Dis Child. 1989; 64: 930-933

[186] Zhou L, Yoshimura Y, Huang Y, et al. Two Independent Pathways of Maternal Cell Transmission to Offspring: Through Placenta during Pregnancy and by Breast-Feeding after Birth. Immunology. 2000; 101:570-580

[187] Hanson LA. Breastfeeding Stimulates the Infant Immune System. Sci Med. 1997; 4: 12-21

[188] Cesar JA, Victora CG, Barros FC, et al. Impact ofBreast Feeding on Admission for Pneumonia during Postneonatal Period in Brazil: nested case-control study. BMJ. 1999; 318: 1316-1320

[189] Black RE, Alderman H, Bhutta ZA, et al. Maternal and Child Nutrition: Building Momentum for Impact. Lancet. 2013; 382: 372-375

[190] Chirico G, Marzollo R, Cortinovis S, et al. Antiinfective Properties of Human Milk. J Nutr. 2008; 138:1801S-1806S 
[191] Bryan DL, Hart PH, Forsyth KD, et al. Immunomodulatory Constituents of Human Milk Change in Response to Infant Bronchiolitis. Pediatr Allergy Immunol. 2007; 18: 495-502

[192] Weber JA, Baxter DH, Zhang S, et al. The MicroRNA Spectrum in 12 Body Fluids. Clin Chem. 2010; 56:1733-1741

[193] Bartel DP. MicroRNAs: Genomics, Biogenesis, Mechanism, and Function. Cell. 2004; 116: 281-297

[194] Krol J, Loedige I, Filipowicz W. The Widespread Regulation of MicroRNA Biogenesis, Function and Decay. Nat Rev Genet. 2010; 11: 597-610

[195] Alsaweed M, Hartmann PE, Geddes DT, et al. MicroRNAs in Breastmilk and the Lactating Breast: Potential Immunoprotectors and Developmental Regulators for the Infant and the Mother. Int J Environ Res Public Health. 2015a; 12: 13981-14020

[196] Kozomara A, Griffiths-Jones S. miRBase: Annotating High Confidence MicroRNAs Using Deep Sequencing Data. Nucleic Acids Res. 2014; 42: D68-73

[197] Alsaweed M, Hepworth AR, Lefevre C, et al. Human Milk microRNA and Total RNA Differ Depending on Milk Fractionation. J Cell Biochem. 2015b; 116:2397-2407

[198] Fallingborg J. Intraluminal pH of the Human Gastrointestinal Tract. Dan Med Bull. 1999; 46: 183-196

[199] Zhou Q, Li M, Wang X, et al. Immune-Related MicroRNAs Are Abundant in Breast Milk Exosomes. Int JBiol Sci. 2012; 8: 118-123

[200] Kosaka N, Iguchi H, Ochiya T. Circulating MicroRNA in Body Fluid: A New Potential Biomarker for Cancer Diagnosis and Prognosis. Cancer Sci 2010; 101:2087-2092

[201] Hata T, Murakami K, Nakatani H, et al. Isolation of Bovine Milk-Derived Microvesicles Carrying mRNAs and MicroRNAs. Biochem Biophys Res Commun.2010; 396: 528-533

[202] Wolf T, Baier SR, Zempleni J. The Intestinal Transport of Bovine Milk Exosomes Is Mediated by Endocytosis in Human Colon Carcinoma Caco-2 Cells and RatSmall Intestinal IEC-6 Cells. J Nutr. 2015; 145: 2201-2206

[203] Baier SR, Nguyen C, Xie F, et al. MicroRNAs Are Absorbed in Biologically Meaningful Amounts from Nutritionally Relevant Doses of Cow Milk and Affect Gene Expression in Peripheral Blood Mononuclear Cells, HEK-293 Kidney Cell Cultures, and Mouse Livers. J Nutr. 2014; 144: 1495-1500 
[204] Zhang Y, Wiggins BE, Lawrence C, et al. Analysis of Plant-Derived miRNAs in Animal Small RNA datasets. BMC Genomics. 2012b; 13: 381

[205] Alsaweed M, Lai CT, Hartmann PE, et al. Human Milk miRNAs Primarily Originate from the Mammary Gland Resulting in Unique miRNA Profiles of Fractionated Milk. Sci Rep. 2015d (Under review)

[206] Alsaweed M, Lai CT, Hartmann PE, et al. Human MilkCells and Lipids Conserve Numerous Known and Novel miRNAs, Some of Which Are Differentially Expressed during Lactatio. BMC Genomics. 2015c(Under review)

[207] Twigger AJ, Hepworth AR, Lai CH, et al. Gene Expression in Breastmilk Cells Is Associated with Maternal and Infant characteristics. Sci Rep. 2015; 5:12933

[208] Silveri L, Tilly G, Vilotte JL, et al. MicroRNA Involvement in Mammary Gland Development and Breast Cancer. Reprod Nutr Dev. 2006; 46: 549-556

[209] Avril-Sassen S, Goldstein LD, Stingl J, et al. Characterisation of MicroRNA Expression in PostNatal Mouse Mammary Gland Development. BMC Genomics. 2009; 10: 548

[210] Li Z, Liu H, Jin X, et al. Expression Profiles of MicroRNAs from Lactating and Non-Lactating Bovine Mammary Glands and Identification of miRNA Related to Lactation. BMC Genomics. 2012; 13: 731

[211] Bian Y, Lei Y, Wang C, et al. Epigenetic Regulation of miR-29 s Affects the Lactation Activity of Dairy Cow Mammary Epithelial Cells. J Cell Physiol. 2015; 230: 2152-2163

[212] Naeem A, Zhong K, Moisa SJ, et al. BioinformaticsAnalysis of MicroRNA and Putative Target Genes in Bovine Mammary Tissue Infected with Streptococcus Uberis. J Dairy Sci. 2012; 95: 6397-6408

[213] Lawless N, Reinhardt TA, Bryan K, et al. MicroRNARegulation of Bovine Monocyte Inflammatory andMetabolic Networks in an in Vivo Infection Model. G3 (Bethesda). 2014; 4: 957-971

[214] Cacho N, Neu J. Refaunation of Donor Human Milk with Mother's Own Milk. FASEB Conference: Origins and Benefits of Biologically Active Components inHuman Milk, Big Sky, Montana, USA, 19-24 July2015

[215] Zani A, Cananzi M, Fascetti-Leon F, et al. Amniotic Fluid Stem Cells Improve Survival and Enhance Repair of Damaged Intestine in Necrotising Enterocolitis Via a COX-2 Dependent Mechanism. Gut. 2014;63: 300-309 
[216] Takahashi K, Tanabe K, Ohnuki M, et al. Induction of Pluripotent Stem Cells from Adult Human Fibroblasts by Defined Factors. Cell. 2007; 131: 861-872

[217] Lee G, Papapetrou EP, Kim H, et al. Modelling Pathogenesis and Treatment of Familial Dysautonomia Using Patient-Specific iPSCs. Nature. 2009; 461: 402-406

[218] Neofytou E, O'Brien CG, Couture LA, et al. Hurdles to Clinical Translation of Human Induced Pluripotent Stem Cells. J Clin Invest. 2015; 125: 2551-2557

[219] Carpenter MK, Frey-Vasconcells J, Rao MS. Developing Safe Therapies from Human Pluripotent Stem Cells. Nat Biotechnol. 2009; 27: 606-613

[220] Zhao T, Zhang ZN, Rong Z, et al. Immunogenicity of Induced Pluripotent Stem Cells. Nature. 2011; 474:212-215

[221] Kim DS, Lee JS, Leem JW, et al. Robust Enhancement of Neural Differentiation from Human ES and iPS Cells Regardless of their Innate Difference in Differentiation Propensity. Stem Cell Rev. 2010; 6: $270-281$

\section{Citations}

1. McManaman JL, Neville MC. Mammary Physiology and Milk Secretion. Adv Drug Deliv Rev. 2003; 55: 629-641ㅌ

2. Jensen RG. Lipids in Human Milk. Lipids 1999; 34: 1243-1271트 3. Kent JC, Mitoulas LR, Cregan MD, et al. Volume and Frequency of Breastfeedings and Fat Contentof Breast Milk throughout the Day. Pediatrics. 2006; 117: e387-395 ㄹ

4. Daly SE, Di Rosso A, Owens RA, et al. Degree of Breast Emptying Explains Changes in the Fat Content, but not Fatty Acid Composition, of Human Milk. Exp Physiol. 1993; 78: 741-75 ㅌ 5. Hassiotou F, Hepworth AR, Williams TM, et al. Breastmilk Cell and Fat Contents Respond Similarly to Removal of Breastmilk by the 
Infant. PLoS One. 2013c; 8: e78232

6. Emmett PM, Rogers IS. Properties of Human Milk and Their

Relationship with Maternal Nutrition. Early Hum Dev. 1997; 49 Suppl:

S7-28

7. Hamosh M. Lipid Metabolism in Pediatric Nutrition. Pediatr Clin North Am. 1995; 42: 839-859

8. Innis SM. Dietary Triacylglycerol Structure and Its Role in Infant Nutrition. Adv Nutr. 2011; 2: 275-283

9. Martin JC, Bougnoux P, Antoine JM, et al. Triacylglycerol Structure of Human Colostrum and Mature Milk. Lipids. 1993; 28: 637-643트 10. Innis SM. Polyunsaturated Fatty Acids in Human Milk: An Essential Role in Infant Development. Adv Exp Med Biol. 2004; 554: $27-43 \subseteq$

11. Nasser R, Stephen AM, Goh YK, et al. The Effect of a Controlled Manipulation of Maternal Dietary Fat Intake on Medium and Long Chain Fatty Acids in Human Breast Milk in Saskatoon, Canada. Int Breastfeed J. 2010; 5: 3 上

12. Ribeiro P, Carvalho FD, Abreu Ade A, et al. Effect of Fish Oil Supplementation in Pregnancy on the Fatty Acid Composition of Erythrocyte Phospholipids and Breast Milk Lipids. Int J Food Sci Nutr. 2012; 63: 36- $40 \subseteq$ 
13. Innis SM. Human Milk: Maternal Dietary Lipids and Infant Development Proc Nutr Soc. 2007; 66: 397- $404 \subseteq$ 14. Straarup EM, Lauritzen L, Faerk J, et al. The Stereospecific Triacylglycerol Structures and Fatty Acid Profiles of Human Milk and Infant Formulas. J Pediatr Gastroenterol Nutr. 2006; 42: 293-299 15. Agostoni C, Caroli M. Role of Fats in the First Two Years of Lifeas Related to Later Development of NCDs. Nutr Metab Cardiovasc Dis. $2012 b ; 2: 775-780 \subseteq$

16. Agostoni C, Caroli M. Role of Fats in the First Two Years of Lifeas Related to Later Development of NCDs. Nutr Metab Cardiovasc Dis. 2012a; 22: 775- 780

17. Fleith M, Clandinin MT. Dietary PUFA for Preterm and Term Infants: Review of Clinical Studies Crit Rev Food Sci Nutr. 2005; 45: $205-229 \subseteq$

18. Tanaka K, Hosozawa M, Kudo N, et al. The Pilot Study: Sphingomyelin-Fortified Milk Has a Positive Association with the Neurobehavioural Development of Very Low Birth Weight Infants during Infancy, Randomized Control Trial. Brain Dev. 2013; 35: 45-52 19. Newburg D. Innate Immunity and Human Milk. J Nutr. 2005; 135: $1308-1312 \ominus$

20. Welsh J, Arsenakis M, May JT. Effect on Semliki Forest Virus and Coxsackievirus B4 of Lipids Common to Human Milk. J Food Safety. 
1981; 3: 99-107

21. Thormar H, Isaacs CE, Brown HR, et al. Inactivation of Enveloped Viruses and Killing of Cells by Fatty Acids and Monoglycerides. Antimicrob Agents Chemother. 1987; 31: 27-31 22. Villamor E, Koulinska IN, Furtado J, et al. Long-Chain n-6 Polyunsaturated Fatty Acids in Breast Milk Decrease the Riskof HIV Transmission through Breastfeeding. Am J Clin Nutr. 2007; 86: 682$689 \triangleq$

23. Hambraeus L, Lonnerdal B, Forsum E, et al. Nitrogen and Protein Components of Human Milk. Acta Paediatr Scand. 1978; 67: 561-565 24. Atkinson SH, Lonnerdal B. Nonprotein Nitrogen Fractions of Human Milk. In: Jensen R (ed). Handbook of Milk Composition. San Deigo, USA: Academic Press, 1995b; 369-387 25. Yu VY. Scientific Rationale and Benefits of Nucleotide Supplementation of Infant Formula. J Paediat Child Health. 2002; 38: $543-549$ ㅌ

26. Carver JD. Dietary Nucleotides: Cellular Immune, Intestinal and Hepatic System Effects. J Nutr. 1994; 124:144S-148S 27. AndreasNJ, Kampmann B, Mehring Le-Doare K. Human breast milk: A Review on its Composition and Bioactivity. Early Hum Dev. $2015 b ; 91: 629-635 \subseteq$ 
28. Chesney RW, Helms RA, Christensen M, et al. The Role of Taurine in Infant Nutrition. Adv Exp Med Biol. 1998; 442: 463-476르 29. Schack-Nielsen L and Michaelsen KF. Advances in our Understanding of the Biology of Human Milk and its Effects on the Offspring. J Nutr. 2007; 137: 503S-510S

30. Goodman JW, Hodgson GS. Evidencefor Stem Cells in the Peripheral Blood of Mice. Blood. 1962; 19: 702-714 트

31. Lönnerdal B, Atkinson SA. Human Milk Proteins. In: Jensen UG (ed). Handbookof Milk Composition. San Diego: Academic Press; 1995 ㅌ 32. Hassiotou F, Geddes DT. Programming of Appetite Control during Breastfeeding as a Preventative Strategy against the Obesity Epidemic. J Hum Lact. 2014; 30: 136-142

33. Martin FP, Moco S, Montoliu I, et al. Impact of Breast-Feeding and High- And Low-Protein Formula on the Metabolism and Growth of Infants from Overweight and Obese Mothers. Pediatr Res. 2014; 75: $535-543 \subseteq$

34. Institute of Medicine. Dietary Reference Intakes for Energy, Carbohydrate, Fiber, Fat, Fatty Acids, Cholesterol, Protein and Amino Acids. Washington, DC: The National Academies Press. 2005 35. Michaelsen KF, Greer FR. Protein Needs Early in Life and LongTerm Health. Am J Clin Nutr. 2014; 99 (suppl): 18S-22S 
36. Michaelsen KF, Larnkjaer A, Molgaard C. Amount and Quality of Dietary Proteins during the First Two Years of Life in Relation to NCD Risk in Adulthood. Nutr Metab Cardiovasc Dis. 2012; 22: 781-786 37. Koletzko B, von Kries R, Closa R, et al. Lower Protein in Infant Formula Is Associated with Lower Weight up to Age 2 Y: A Randomized Clinical Trial. Am J Clin Nutr 2009; 89: 1836-1845 38. Socha P, Grote V, Gruszfeld D, et al. Milk Protein Intake, the Metabolic-Endocrine Response, and Growth in Infancy: Data from a Randomized Clinical Trial. Am J Clin Nutr. 2011; 94 (suppl): 1776S$1784 \mathrm{~S}_{\subseteq}$

39. Czank C. Human Milk Composition - Nitrogen and Energy Content. In: Hale TWand Hartmann PE (eds). Textbookof Human Lactation. Amarillo, Texas: Hale Publishing, LP; 2007: 75-88 40. Bounous G, Kongshavn PA, Taveroff A, et al. Evolutionary Traits in Human Milk Proteins. Med hypotheses. 1988; 27: 133-140 41. Kunz C, Lönnerdal B. Re-Evaluation of the whey Protein/Casein Ratio of Human Milk. Acta Pædiatr. 1992; 81:107-11 42. Ewer AK, Durbin GM, Morgan ME, et al. Gastric Emptying in Preterm Infants. Arch Dis Child Fetal Neonatal Ed. 1994; 71: F24-27 43. Cavell B. Gastric Emptying in Infants Fed Human Milkor Infant Formula. Acta Paediatr Scand. 1981; 70: 639-641 
44. Van den Driessche M, Peeters K, Marien P, et al. Gastric Emptying in Formula-Fed and Breast-Fed Infants Measured with the 13COctanoic Acid Breath Test. J Pediatr Gastroenterol Nutr. 1999; 29: 46-51

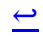

45. Davies DT, Holt C, Christie WW. The Composition of Milk. In: Mepham TB (ed). Biochemistry of lactation. Amsterdam: Elsevier; 1983: 71-117

46. Newton ER. Breastmilk: The Gold Standard. Clin Obstet Gynecol. 2004; 47: 632-642

47. Mange A, Bellet V, Tuaillon E, et al. Comprehensive Proteomic Analysis of the Human Milk Proteome: Contribution of Protein Fractionation. J Chromatogr B Analyt Technol Biomed Life Sci. 2008; 876: 252- 256 48. D’Alessandro A, Scaloni A, Zolla L. Human Milk Proteins: An Interactomics and Updated Functional Overview. J Proteome Res. 2010; 9: 3339-3373ㅂ

49. Lonnerdal B, Iyer S. Lactoferrin: Molecular Structure and Biological Function. Ann Rev Nutr. 1995; 15: 93-110 50. Kawakami H, Lonnerdal B. Isolation and Function of a Receptor for Human Lactoferrin in Human Fetal Intestinal Brush-Border Membranes. Am J Physiol. 1991; 261: G841-846르 
51. Suzuki YA, Lonnerdal B. Characterization of Mammalian Receptors for Lactoferrin. Biochem Cell Biol. 2002; 80: 75-80 52. Chierici R, Sawatzki G, Tamisari L, et al. Supplementation of an Adapted Formula with Bovine Lactoferrin. 2. Effects on serum iron, ferritin and zinc levels. Acta Paediatr. 1992; 81: 475-479르 53. Johnston WH, Ashley C, Yeiser M, et al. Growth and Tolerance of Formula with Lactoferrin in Infants through One Year of Age: DoubleBlind, Randomized, Controlled Trial. BMC Pediatr. 2015; 15: 173 ㅌ 54. Davidson LA, Lonnerdal B. Specific Binding of Lactoferrin to Brush-Border Membrane: Ontogeny and Effect of Glycan Chain. Am J Physiol. 1988; 254: G580-585 르

55. Arnold RR, Brewer M, Gauthier JJ. Bactericidal Activity of Human Lactoferrin: Sensitivity of a Variety of Microorganisms. Infect Immun. 1980; 28: 893-898 56. Tomita M, Bellamy W, Takase M, et al. Potent Antibacterial Peptides Generated by Pepsin Digestion of Bovine Lactoferrin. J Dairy Sci. 1991; 74: $4137-4142$ 57. Gifford JL, Hunter HN, Vogel HJ. Lactoferricin: A LactoferrinDerived Peptide with Antimicrobial, Antiviral, Antitumor and Immunological Properties. Cell Mole Life Sci. 2005; 62: 2588-2598 ㅌ 58. Chipman DM and Sharon N. Mechanism of Lysozyme Action. Science. 1969; 165: 454-465 ㅌ 
59. Ellison RT, 3rd, Giehl TJ. Killing of Gram-Negative Bacteria by Lactoferrin and Lysozyme. J Clin Invest. 1991; 88: 1080-1091 르 60. Leon-Sicairos N, Lopez-Soto F, Reyes-Lopez M, et al. Amoebicidal Activity of Milk, Apo-Lactoferrin, sIgA and Lysozyme. Clin Med Res. 2006; $4: 106-113 \subseteq$

61. Lee-Huang S, Maiorov V, Huang PL, et al. Structural and Functional Modeling of Human Lysozyme Reveals a Unique Nonapeptide, HL9, with Anti-HIVActivity. Biochemistry. 2005; 44: 4648-4655 62. Minami J, Odamaki T, Hashikura N, et al. Lysozyme in Breast Milk Is a Selection Factor for Bifidobacterial Colonisation in the Infant Intestine. Benef Microbes. 2015; Oct 27: 1-8 63. Oliver WT, Wells JE. Lysozyme as an Alternativeto Growth Promoting Antibiotics in Swine Production. J Anim Sci Biotechnol. $2015 ; 6: 35$ 트

64. Braun OH, Sandkuhler H. Relationships between Lysozyme Concentration of Human Milk, Bacteriologic Content, and Weight Gain of Premature Infants. J Pediatr Gastroenterol Nutr. 1985; 4: 583586

65. Christen L, Lai CT, Hartmann B, et al. The effect of UV-C Pasteurization on Bacteriostatic Properties and Immunological Proteins of Donor Human Milk. PLoS One. 2013a; 8: e85867 ㅌ 
66. Atkinson SH, Lonnerdal B. Nitrogenous Components of Milk. In: Jensen R (ed). Handbookof Milk Composition. San Diego, USA: Academic Press; 1995a: 351-368 67. Brew K, Hill RL. Lactose Biosynthesis. Rev Physiol Biochem Pharmacol. 1975; 72: 105-158 트 68. Ren J, Stuart DI, Acharya KR. Alpha-Lactalbumin Possesses a Distinct Zinc Binding Site. J Biolog Chem. 1993; 268: 19292-19298 브 69. Lonnerdal B, Glazier C. Calcium Binding by AlphaLactalbumin in Human Milk and Bovine Milk. J Nutr. 1985; 115: 1209-1216 70. Kelleher SL, Chatterton D, Nielsen K, et al. Glycomacropeptideand Alpha-Lactalbumin Supplementation of Infant Formula Affects Growth and Nutritional Status in Infant Rhesus Monkeys. Am J Clin Nutr. 2003; 77: 1261-1268

71. Forsum E. Nutritional Evaluation of Whey Protein Concentrates and their Fractions. J Dairy Sci. 1974; 57: 665-670 72. Lonnerdal B. Nutritional and Physiologic Significance of Human Milk Proteins. Am J Clin Nutr. 2003; 77: 1537S-1543S 트 73. Chatterton DE, Nguyen DN, Bering SB, et al. Anti-Inflammatory Mechanisms of Bioactive Milk Proteins in the Intestine of Newborns. Int J Biochem Cell Biol. 2013; 45: 1730-1747트 74. Goldman AS, Goldblum RM. Defense Agents in Milk. In: Jensen R (ed). Handbookof Milk Composition. San Diego, USA: Academic Press; 
1995: 727-74

75. Lewis-Jones DI, Lewis-Jones MS, Connolly RC et al. Sequential changes in the antimicrobial protein concentrations in human milkduring lactation and its relevanceto banked human milk. Pediatr. Res. 1985; 19: 561-565

76. Goldblum RM, Ahlstedt S, Carlsson B, et al. Antibody-Forming Cells in Human Colostrum after Oral Immunisation. Nature. 1975; 257: 797$798 \subseteq$

77. Hanson LA, Korotkova M. The Role of Breastfeeding in Prevention of Neonatal Infection. Semin Neonatol. 2002; 7: 275-281 78. Arnold JN, Wormald MR, Sim RB, et al. The Impact of Glycosylation on the Biological Function and Structure of Human Immunoglobulins. Ann Rev Immunol 2007; 25: 21-50 79. Blackberg L, Hernell O. Further Characterization of the Bile SaltStimulated Lipase in Human Milk. FEBS Lett. 1983; 157: 337-341ㅌ 80. Tully DB, Jones F, Tully MR. Donor Milk: What's in It and What's Not. J Hum Lact. 2001; 17: 152-155 81. Andersson Y, Savman K, Blackberg L, et al. Pasteurization of Mother's Own Milk Reduces Fat Absorption and Growth in Preterm Infants. Acta Paediatr. 2007; 96: 1445-1449트 82. Christen L, Lai CT, Hartmann B, et al. Ultraviolet-C Irradiation: A NovelPasteurization Method forDonor Human Milk. PLoS One.2013b; 
$8: \mathrm{e} 68120 \subseteq$

83. da Silva AP, Ellen RP, Sorensen ES, et al. Osteopontin Attenuation of Dextran Sulfate Sodium-Induced Colitis in Mice. Lab Invest. 2009; 89: $1169-1181 \subseteq$

84. Donovan SM, Monaco MH, Drnevich J, et al. Bovine Osteopontin Modifies the Intestinal Transcriptome of Formula-Fed Infant Rhesus Monkeys to Be More Similar toThose That Were Breastfed. J Nutr. 2014a; 144: 1910-1919

85. Lonnerdal B, Kvistgaard AS, Peerson JM, et al. Growth, Nutrition and Cytokine Response of BreastFed Infants and Infants Fed Formula with Added Bovine Osteopontin. J Pediatr Gastroenterol Nutr. 2016; 62: $650-657 \subseteq$

86. Lindberg T, Ohlsson K, Westrom B. Protease Inhibitors and their RelationtoProteaseActivity in Human Milk. Pediatr Res. 1982; 16: 479483

87. Mellersh A, Clark A, Hafiz S. Inhibition of Neisseria Gonorrhoeae by Normal Human Saliva. Br J Vener Dis. 1979; 55: 20-23. 88. Sandberg DP, Begley JA, Hall CA. The Content, Binding, and Forms of Vitamin B12 in Milk. Am J Clin Nutr. 1981; 34: 1717-1724 89. Adkins Y, Lonnerdal B. Mechanisms of Vitamin B(12) Absorption in Breast-Fed Infants. J Pediatr Gastroenterol Nutr. 2002; 35: 192-198 
90. Chollet-Hinton LS, Stuebe AM, Casbas-Hernandez P, et al.

Temporal Trends in the Inflammatory Cytokine Profile of Human Breastmilk. Breastfeed Med. 2014; 9: 530-537ㅌ 91. Fields DA, Demerath EW. Relationship of Insulin, Glucose, Leptin, IL-6 and TNF-alpha in Human Breast Milk with Infant Growth and Body Composition. Pediatr Obes. 2012; 7: 304-312 92. Donovan SM, Odle J. Growth Factors in Milk As Mediators of Infant Development. Ann Rev Nutr. 1994; 14: 147-167 93. Frost BL, Jilling T, Lapin B, et al. Maternal Breast Milk Transforming Growth Factor-Beta and Feeding Intolerance in Preterm Infants. Pediatr Res. 2014; 76: 386-393 94. Maheshwari A, Kelly DR, Nicola T, et al. TGF-Beta2 Suppresses Macrophage Cytokine Production and Mucosal Inflammatory Responses in the Developing Intestine. Gastroenterology. 2011; 140: $242-253$ 95. Groer M, Duffy A, Morse S, et al. Cytokines, Chemokines, and Growth Factors in Banked Human Donor Milk for Preterm Infants. J Hum Lact. 2014; 30: 317- 323 ㅌ 96. Neville MC. Physiology of Lactation. Clin Perinatol. 1999; 26: 251$279 \subseteq$

97. Kulski JK, Hartmann PE. Changes in Human Milk Composition during the Initiation of Lactation. Aust J Exp Biol Med Sci. 1981; 59: 
$101-114 \subseteq$

98. Newburg DS, Neubauer SH. Carbohydrates in Milks: Analysis, Quantities and Significance. In:Jensen RG (ed). Handbookof Milk Composition. San Diego, USA: Academic Press; 1995 99. German JB, Freeman SL, Lebrilla CB, et al. Human Milk Oligosaccharides: Evolution,Structures and Bioselectivity as Substrates for Intestinal Bacteria. Nestle NutrWorkshop Ser Pediatr Program. 2008; 62: 205-218; discussion 218-222 100. Bode L. Human Milk Oligosaccharides: Every Baby Needs a Sugar Mama. Glycobiology. 2012; 22: 1147-1162 101. Newburg DS. Glycobiology of Human Milk. Biochemistry (Mosc). 2013; 78: 771-785 102. Alderete TL, Autran C, Brekke BE, et al. Associations between Human Milk Oligosaccharides and Infant Body Composition in the First 6 Mo of Life. Am J Clin Nutr. 2015; 102: 1381-1388 103. Wang B, McVeagh P, Petocz P, et al. Brain Ganglioside and Glycoprotein Sialic Acid in Breastfed Compared with Formula-Fed Infants. Am J Clin Nutr. 2003; 78: 1024-1029巳 104. Kuhn L, Kim HY, HsiaoL, etal. Oligosaccharide Composition of Breast Milk Influences Survival of Uninfected Children Born to HIVInfected Mothers in Lusaka, Zambia. J Nutr. 2015; 145: 66-72 
105. Jantscher-Krenn E, Lauwaet T, Bliss LA, et al. Human Milk Oligosaccharides Reduce Entamoeba Histolytica Attachment and Cytotoxicity in Vitro. Br J Nutr. 2012; 108: 1839-1846ㄹ 106. Bode L. The Functional Biology of Human Milk Oligosaccharides. Early Hum Dev. 2015; 91: 619-622 107. Gonia S, Tuepker M, Heisel T, et al. Human Milk Oligosaccharides Inhibit Candida Albicans Invasion of Human Premature Intestinal Epithelial Cells. J Nutr. 2015; 145: 1992-1998 108. Zivkovic AM, German JB, Lebrilla CB, et al. Human Milk Glycobiome and Its Impact on the Infant Gastrointestinal Microbiota. Proc Natl Acad Sci USA. 2011; 108 Suppl 1: 4653-4658 르 109. Picciano MF. Nutrient Composition of Human Milk. Pediatr Clin North Am. 2001; 48: 53-67

110. Allen LH. Multiple Micronutrients in Pregnancy and Lactation: An Overview. The Am J Clin Nutr. 2005; 81: 1206S-1212S 111. Ala-Houhala M, KoskinenT, Parviainen MT, et al. 25Hydroxyvitamin D and Vitamin D in Human Milk: Effects of Supplementation and Season. Am J Clin Nutr. 1988; 48: 1057-1060 112. Greer FR, Hollis BW, Cripps DJ, et al. Effects of Maternal Ultraviolet B Irradiation on Vitamin D Content of Human Milk. J Pediatr. 1984; 105: 431-433 ㅌ 
113. Specker BL, Tsang RC, Hollis BW. Effect of Raceand Dieton HumanMilk Vitamin D and 25-Hydroxyvitamin D. Am J Dis Child. 1985; 139: $1134-113$ 巳

114. Pugliese MT, Blumberg DL, Hludzinski J, et al. Nutritional Rickets in Suburbia. J Am Coll Nutr. 1998; 17: 637-641ㅌ 115. Thiele DK, Senti JL, Anderson CM. Maternal Vitamin D Supplementation to Meet the Needs of the Breastfed Infant: A Systematic Review. J Hum Lact. 2013; 29: 163-170 116. Wagner CL, Greer FR. Prevention of Rickets and Vitamin D Deficiency in Infants, Children, and Adolescents. Pediatrics. 2008; 122: $1142-1152$ ㅌ

117. Georgieff MK, Wewerka SW, Nelson CA, et al. Iron Status at 9 Months of Infants with Low Iron Stores at Birth. J Pediatr. 2002; 141: $405-409$ 트

118. Krebs NF, Sherlock LG, Westcott J, et al. Effects of Different Complementary Feeding Regimens on Iron Status and Enteric Microbiota in Breastfed Infants. J Pediatr. 2013; 163: 416-423 119. Friel JK, Aziz K, Andrews WL, et al. A double-Masked, Randomized Control Trial of Iron Supplementation in Early Infancy in Healthy Term Breast-Fed Infants. J Pediatr. 2003; 143: 582-586ㄹ 120. Baker RD, Greer FR. Diagnosis and Prevention of Iron Deficiency and Iron-Deficiency Anemia in Infants and Young Children (0-3 
Years of Age). Pediatrics. 2010; 126: 1040-1050

121. Gibson RS. A Historical Review of Progress in the Assessment of Dietary Zinc Intakeas an Indicator of Population Zinc Status. Adv Nutr. 2012; 3: 772-782

122. Brown KH, Rivera JA, Bhutta Z, et al. International Zinc Nutrition Consultative Group (IZiNCG) Technical Document \#1. Assessment of the riskof zinc deficiency in populations and options for its control. Food Nutr Bull. 2004; 25: S99-203 123. Krebs NF, Miller LV, Hambidge KM. Zinc Deficiency in Infants and Children: A Review of its Complex and Synergistic Interactions. Paediatr Int Child Health. 2014; 34: 279-288 124. Rautava S, LuotoR, Salminen S, et al. Microbial Contact during Pregnancy, Intestinal Colonization and Human Disease. Nat Rev Gastroenterol Hepatol. 2012; 9: 565-576ㅌ 125. Donovan SM, Wang M, Monaco MH, et al. Noninvasive Molecular Fingerprinting of Host-Microbiome Interactions in Neonates. FEBS Lett. 2014b; 588: 4112-4119 126. Bezirtzoglou E, Tsiotsias A, Welling GW. Microbiota Profile in Feces of Breast- and Formula-Fed Newborns by Using Fluorescence in Situ Hybridization (FISH). Anaerobe. 2011; 17: 478-482 트 127. Hunt KM, Foster JA, Forney LJ, et al. Characterization of the Diversity and Temporal Stability of Bacterial Communities in Human 
Milk. PLoS One 2011; 6: e21313

128. Turnbaugh PJ, Ridaura VK, Faith JJ, et al. The Effect of Dieton the Human Gut Microbiome: A Metagenomic Analysis in Humanized Gnotobiotic Mice. Sci Transl Med. 2009; 1: 6ra14 129. Cabrera-Rubio R, Collado MC, Laitinen K, et al. The Human Milk Microbiome Changes over Lactation and Is Shaped by Maternal Weight and Mode of Delivery. Am J Clin Nutr. 2012b 96: 544-55 130. Azad MB, Konya T, Persaud RR, et al. Impact of Maternal Intrapartum Antibiotics, Method of Birth and Breastfeeding on Gut Microbiota during the First Year of Life: A Prospective Cohort Study. BJOG. 2016; 123: 983-993

131. Fouhy F, Ross RP, Fitzgerald GF, et al. Composition of the Early Intestinal Microbiota: Knowledge, Knowledge Gaps and the Use of High-Throughput Sequencing to Address these Gaps. Gut Microbes. 2012; 3: 203-220

132. Tanaka S, Kobayashi T, Songjinda $P$, et al. Influence of Antibiotic Exposure in the Early Postnatal Period on the Development of Intestinal Microbiota. FEMS Immunol Med Microbiol. 2009; 56: 80-87

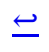

133. Soto A, Martin V, Jimenez E, et al. Lactobacilliand Bifidobacteria in Human Breast Milk: Influence of Antibiotherapy and Other Host and Clinical Factors. J Pediatr Gastroenterol Nutr. 2014; 59: 78-88 
134. Yu Z, Chen C, McCoy JM, Liu B, et al. The Principle Fucosylated Oligosaccharides of Human Milk Exhibit Prebiotic Properties on Cultured Infant Microbiota. 16th International Conference of the Society for Research into Human Milk and Lactation. Trieste, Italy; 2012 巳

135. Rogier EW, Frantz AL, Bruno ME, et al. Secretory Antibodies in Breast Milk Promote Long-Term Intestinal Homeostasis by Regulating the Gut Microbiota and Host Gene Expression. Proc Natl Acad Sci USA. 2014; 111: 3074-3079 136. Fernandez L, Langa S, Martin V, et al. The Human Milk Microbiota: Origin and Potential Roles in Health and Disease. Pharmacol Res. 2013; 69: 1-10 137. Woo JG, Martin LJ. Does Breastfeeding Protect Against Childhood Obesity? Moving beyond observational evidence. Curr Obes Rep. 2015; 4: 207-216브 138. Dewey KG, Lonnerdal B. Infant Self-Regulation of Breast Milk Intake. Acta Paediatr Scand 1986; 75: 893-898 139. Li R, Scanlon KS, May A, et al. Bottle-Feeding Practices during Early Infancy and Eating Behaviors at 6 Years of Age. Pediatrics. 2014; 134 Suppl 1: S70-77트

140. Li R, Fein SB, Grummer-Strawn LM. Association of Breastfeeding Intensity and Bottle-Emptying Behaviors at Early Infancy with 
Infants' Risk for Excess Weight at Late Infancy. Pediatrics. 2008; 122 Suppl 2: S77-84

141. Savino F, Liguori SA, Fissore MF, et al. Breast Milk Hormones and their Protective Effect on Obesity. Int J Pediatr Endocrinol. 2009; 2009: $327505 \subseteq$

142. Maffei HV, Nobrega FJ. Gastric $\mathrm{pH}$ and Microflora of Normal and Diarrhoeic Infants. Gut. 1975; 16: 719- 726트 143. Van Elburg RM, Uil JJ, de Monchy JG, et al. Intestinal Permeability in Pediatric Gastroenterology. Scand J Gastroenterol Suppl. 1992; 194: $19-24 \subseteq$

144. Barrenetxe J, Villaro AC, Guembe L, et al. Distribution of the Long Leptin Receptor Isoform in Brush Border, Basolateral Membrane, and Cytoplasm of Enterocytes. Gut. 2002; 50: 797-802

145. Chowanadisai Wand Lonnerdal B. Alpha(1)-Antitrypsin and Antichymotrypsin in Human Milk: Origin, Concentrations, and Stability. Am J Clin Nutr. 2002; 76: 828-833트 146. Wada Y, Lonnerdal B. Bioactive Peptides Derived from Human Milk Proteins-Mechanisms of Action. J Nutr Biochem. 2014; 25: 503514 巳

147. Klein S, Coppack SW, Mohamed-Ali V, et al. Adipose Tissue Leptin Production and Plasma Leptin Kinetics in Humans. Diabetes 1996; 45 : 984-987巳 
148. Cinti S, Matteis RD, Pico C, et al. Secretory Granules of Endocrine and Chief Cells of Human Stomach Mucosa Contain Leptin. Int J Obes Relat Metab Disord. 2000; 24:789-793

149. Masuzaki H, Ogawa Y, Sagawa N, et al. Nonadipose Tissue Production of Leptin: Leptin as a Novel Placenta-Derived Hormone in Humans. Nat Med. 1997; 3: 1029-1033 트 150. Hassiotou F, Savigni D, Hartmann PE, et al. Appetite Hormones Present in Breastmilk Can Be Synthesized by Mammary Cells during Lactation. Bi-annual Conference of International Society for Research in Human Milk and Lactation. Charleston, South Carolina, USA, October 2014.2014c

151. Hassiotou F, Lai CT, Filgueira L, et al. Mammary Cells Synthesize Insulin during Lactation. FASEB J. 2014b; 28 ㅌ 152. Hassiotou F, Savigni D, Hartmann PE, et al. Mammary Cells Synthesize Appetite Hormones That May Contribute to Breastmilk. FASEB J, 2014d; 28 ㄴ

153. Quinn EA, Largado F, Borja JB, et al. Maternal Characteristics Associated with Milk Leptin Content in a Sample of Filipino Women and Associations with Infant Weight for Age. J Hum Lact. 2015; 31: 273$281 \subseteq$

154. Weyermann M, Brenner H, Rothenbacher D. Adipokines in Human Milk and Riskof Overweight in early childhood: a prospective 
cohort study. Epidemiology. 2007; 18: 722-729 155. Cabrera W, Knapp J. Metabolomics: Metabolites, Metabonomics, and Analytical Technologies, New York: Nova Science Publishers, Inc.; $2011_{\Perp}$

156. Dessi A, Cesare Marincola F, Masili A, et al. Clinical Metabolomics and Nutrition: The New Frontier in Neonatology and Pediatrics. Biomed Res Int. 2014; 2014: 981219 157. Cesare Marincola F, Dessi A, Corbu S, et al. Clinical Impact of Human Breast Milk Metabolomics. Clin Chim Acta. 2015; 451: 103-106 $\pm$

158. Zhang A, Sun H, Wang P, et al. Recent and Potential Developments of Biofluid Analyses in Metabolomics. J Proteomics. 2012a; 75: 1079$1088=$

159. Marincola FC, NotoA, Caboni P, et al. A Metabolomic Study of Preterm Human and Formula Milk by High Resolution NMR and GC/MS Analysis: Preliminary Results. J Matern Fetal Neonatal Med. 2012; 25: 62-67巳

160. Longini M, Tataranno ML, Proietti F, et al. A Metabolomic Study of Preterm and Term Human and Formula Milk by Proton MRS Analysis: Preliminary Results. J Matern Fetal Neonatal Med. 2014; 27 Suppl 2: $27-33$ 
161. Smilowitz JT, O'Sullivan A, Barile D, et al. The Human Milk Metabolome Reveals Diverse Oligosaccharide Profiles. J Nutr. 2013; 143: $1709-1718$ ㅌ

162. Mateos-Vivas M, Rodriguez-Gonzalo E, DominguezAlvarez J, et al. Analysis of Free Nucleotide Monophosphates in Human Milk and Effect of Pasteurisation or High-Pressure Processing on their Contents by Capillary Electrophoresis Coupled to Mass Spectrometry. Food Chem. 2015; 174: 348-355 ㅌ 163. Albrecht S, Schols HA, van den Heuvel EG, et al. CELIF-MSn Profiling of Oligosaccharides in Human Milk and Feces of Breast-fed Babies. Electrophoresis 2010; 31: 1264-1273 164. Villasenor A, Garcia-Perez I, Garcia A, et al. Breast Milk Metabolome Characterization in a Single-Phase Extraction, Multiplatform Analytical Approach. Anal Chem. 2014; 86: 8245-8252 165. AndreasNJ, Hyde MJ, Gomez-Romero M, et al. Multiplatform Characterization of Dynamic Changes in Breast Milkduring Lactation. Electrophoresis. 2015a; May 11. doi: 10.1002/elps.201500011. [Epub ahead of print $]_{\Perp}$ 166. Newburg DS, Morelli L. Human Milk and Infant Intestinal Mucosal Glycans Guide Succession of the Neonatal Intestinal Microbiota. Pediatr Res. 2015; 77: 115-120 
167. Cabrera-Rubio R, Collado MC, Laitinen K, et al. The Human Milk Microbiome Changes over Lactation and Is Shaped by Maternal Weight and Mode of Delivery. Am J Clin Nutr. 2012a; 96: 544-551 168. Donné A. Du lait et en particulier de celui de nourrices, considéré sous le rapport de ses bonnes et de ses mavaises qualités nitritives et de ses altérations. Paris, Rue de Condé: no 15; Les Libraires de Médecine, Chevalier, Palais Royal, no 163; 1837 ㅌ

169. Henle J. Allgemeine Anatomie. 2 Aufl., L. Voss, Leipzig, Germany $1841 \subseteq$

170. Holmquist DG, Papanicolaou GN. The Exfoliative Cytologyof the Mammary Gland during Pregnancy and Lactation. Ann N YAcad Sci. 1956; 63: $1422-1435$ 트

171. Hassiotou F, Beltran A, Chetwynd E, et al. Breastmilk Is a NovelSourceof Stem Cells with MultilineageDifferentiation Potential. Stem cells. 2012a; 30: 2164- 2174 ㅌ

172. Hassiotou F, Geddes DT, Hartmann PE. Cells in Human Milk: State of the Science. J Hum Lact. 2013a; 29: 171-182 173. Hassiotou F, Hartmann PE. At the Dawn of a New Discovery: The Potential of Breastmilk Stem Cells. Adv Nutr. 2014; 5: 770-778 174. Hassiotou F, Hepworth AR, Metzger P, et al. Maternal and Infant Infections Stimulate a Rapid Leukocyte Response in Breastmilk. ClinTranslat Immunol. 2013b; 2: e3 
175. Hassiotou F, Geddes D. Immune Cell-Mediated Protection of the Mammary Gland and the Infant during Breastfeeding. Adv Nutr. $2015 ; 6: 267-275$

176. Hassiotou F, Hepworth AR, Williams TM, et al. Breastmilkcell and fat contents respond similarly to removal of breast milk by the infant. PLoS One. 2013d; 8: e78232

177. Riskin A, Almog M, Peri R, et al. Changes in Immunomodulatory Constituents of Human Milk in Response to Active Infection in the Nursing Infant. Pediatr Res. 2012; 71: 220-225 